Florida International University FIU Digital Commons

$1-19-2005$

\title{
Monstrum in femine figura : the patriarchal devaluation of the Irish goddess, the Mor-rioghan
}

Kelley Flannery Rowan

Florida International University, Kelley.Rowan@fiu.edu

DOI: $10.25148 /$ etd.FI14030210

Follow this and additional works at: https://digitalcommons.fiu.edu/etd

Part of the Religion Commons

\section{Recommended Citation}

Rowan, Kelley Flannery, "Monstrum in femine figura : the patriarchal devaluation of the Irish goddess, the Mor-rioghan" (2005). FIU Electronic Theses and Dissertations. 1058.

https://digitalcommons.fiu.edu/etd/1058 


\section{FLORIDA INTERNATIONAL UNIVERSITY}

Miami, Florida

MONSTRUM IN FEMINE FIGURA: THE PATRIARCHAL DEVALUATION OF THE IRISH GODDESS, THE MOR-RÍOGHAN

A thesis submitted in partial fulfillment of the

requirements for the degree of

MASTER OF ARTS

in

RELIGIOUS STUDIES

by

Kelley Flannery Rowan

2005 
To: Dean R. Bruce Dunlap

College of Arts and Sciences

This thesis, written by Kelley Flannery Rowan, and entitled Monstrum in Femine Figura: The Patriarchal Devaluation of the Irish Goddess, The Mor-rioghan, having been approved in respect to style and intellectual content, is referred to you for judgment.

We have read this thesis and recommend that it be approved.

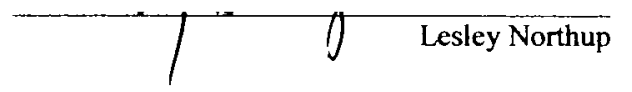

Erik Larson

Christine Gudorf thajor Professor

Date of Defense: January 19, 2005

The thesis of Kelley Flannery Rowan is approved.

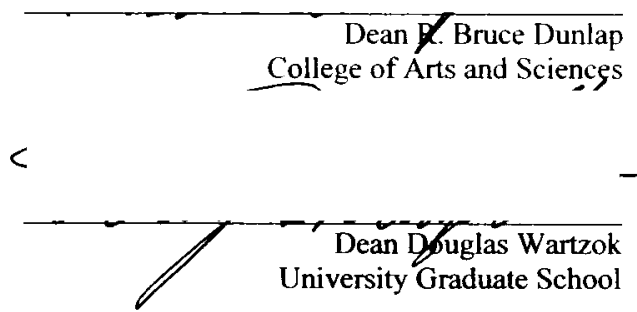

Florida International University, 2005 


\section{ABSTRACT OF THE THESIS}

MONSTRUM IN FEMINE FIGURA: THE PATRIARCHAL DEVALUATION OF

\section{THE IRISH GODDESS, THE MOR-RÍOGHAN}

by

Kelley Flannery Rowan

Florida International University, 2005

Miami, Florida

Professor Christine Gudorf, Major Professor

This work explores the transformation and eventual demotion of the goddess in ancient Ireland through the evolution of patriarchal mythos and as a consequence of economic factors, socio-political and religious manifestations, as well as agricultural developments. The purpose of this paper is to examine the relationship between leading theories of social, cultural and religious change in prehistory and early history and the historical process of the demotion of the Irish goddess figure, the Mor-rioghan. The Mor-rioghan is the subject of exploration as her militarization and subsequent incarnation as a bean si have resulted in her near dissolution. The decline of the goddess's status will be explained as inevitable in the face of the evolving hierarchies of androcentric theologies. 


\section{TABLE OF CONTENTS}

CHAPTER

PAGE

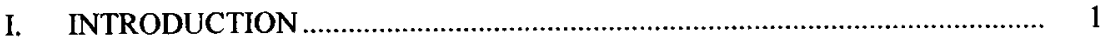

The Mor-rioghan ……......................................................................................

Etymology of the Mor-rioghan ..................................................................... 5

The Triune Nature of the Mor-rioghan .............................................................. 7

The Devaluation of the Irish Goddess ................................................................. 9

Stages in the Demotion of the Goddess, the Mor-rioghan ............................... 10

II. THE GODDESS OF MATRISTIC CULTURE ...................................... 13

Gimbutas's Research ............................................................................... 15

Demotion of the Goddess.......................................................................... 26

The Mor-rioghan and Gimbutas..................................................................... 28

III. DEVALUATION IN AGRARIAN SOCIETY ……................................... 35

Transition to an Agrarian Lifestyle ................................................................ 38

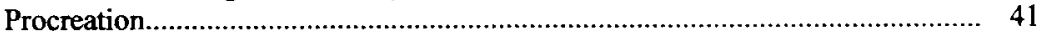

Private Property, Wealth, and Greed........................................................... 42

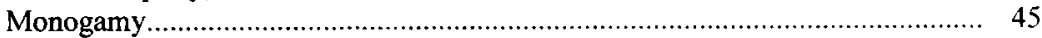

Elements of Transition and Devaluation...................................................... 46

The Importance of the Irish Landscape .............................................................. 48

The Goddess in Transition ............................................................................ 51

IV. SOVEREIGNTY AND WARFARE ........................................................ 54

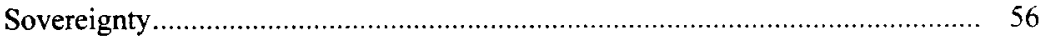

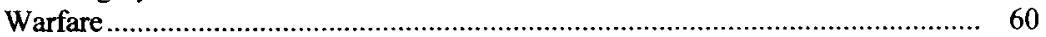

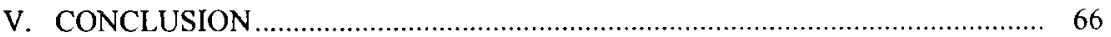

Brigid as Pagan Goddess and Christian Saint ................................................. 69

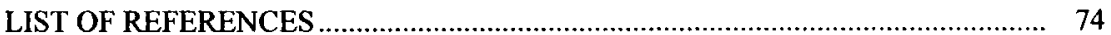




\section{CHAPTER ONE}

\section{CIRCUMSCRIPTION OF THE TOPIC}

This work explores the transformation and eventual demotion of the goddess in ancient Ireland through the evolution of patriarchal mythos and as a consequence of economic factors, socio-political and religious manifestations, as well as agricultural developments. The purpose of this paper is to examine the relationship between leading theories of social, cultural and religious change in prehistory and early history and the historical process of the demotion of the Irish goddess figure, the Mor-rioghan. The Mor-rioghan ${ }^{1}$ is the subject of exploration as her militarization and subsequent incarnation as a bean $s i^{2}$ have resulted in her near dissolution. The decline of the goddess's status will be explained as inevitable in the face of the evolving hierarchies of androcentric theologies.

The study is organized into four major sections. The first part addresses the research of Marija Gimbutas as an aid in understanding the role of the Goddess and the possibility of goddess-centered civilization. In contrast to Gimbutas' work are the criticisms of Cynthia Eller, a critical feminist writer, who is strictly opposed to the "matriarchal myth" she believes to be present in Gimbutas's research. However, a closer exploration of Eller's criticisms reveals more accurately the true source of her antipathy; a particular group of feminist writers who came after Gimbutas and who drew inspiration

\footnotetext{
'The Mor-rioghan is a goddess belonging to Irish Celtic mythology who is best known for her skill on the battlefield, not as a warrior, but for her poetry and magic, and as a shape shifter.

${ }^{2}$ A Bean st (banshee) is a supernatural death messenger in Irish mythology. She is a solitary ghostly female figure that comes for the souls of the recently deceased. She is also known as Badb, one of the Trinitarian aspects of the Mor-rioghan, especially in the south of Ireland.
} 
from her work while largely misinterpreting her research as promoting a matriarchal prehistory.

Eller herself often seems to misunderstand the true source of her angst, directing it at Gimbutas rather than the later offending crowd of largely popular non-academic writers who made the leap from goddess-centered to matriarchal. However, her criticisms often bring to light some questions of interpretation within Gimbutas's research and therefore provide a valuable argument in contrast to currently evolving theories of matriarchal prehistory. For this reason, her works will be a major source providing counter arguments regarding women in prehistory.

The second section addresses the beginnings of devaluation for both the Goddess in general and more specifically for the Irish goddess, the Mor-rioghan. The chapter begins with the effects of the agricultural revolution and includes a discussion on the various socio-political and religious structures, which were the consequence of this monumental lifestyle change, such as: private property, accumulation of wealth, population growth, new concerns in procreation, and monogamy.

The spread of agrarian techniques and knowledge of animal husbandry brought awareness of paternity issues, and thus affected the role and status of women both in reality and within religious imagination. The goddess's role was transformed, along with society, as communities adopted settled agriculture and issues of private property and surplus arose.

From these cultural developments emerged a further set of developments, such as sovereignty and a warrior aristocracy, both born out of a culture in which warfare had become the norm. The mythology of this culture appears, at least in the initial stages, to 
offer a place of prestige for the goddess. However, as the unconscious unfolding of history and mythology continued, she was marginalized precisely because of her role as a sovereignty goddess in a culture based on warfare. Warfare and sovereignty are the necessary subject of the third section and entail a study of some of the best-known sovereignty myths of Ireland, many of which have been a source of feminist exploration and discussion.

The final section addresses the current incarnation of the Mor-rioghan as a bean si, a female death messenger. The history of bean si lore is explored, including how the Irish connected the bean si to the Mor-rioghan. Additionally, this section looks briefly at the goddess Brigid, thought to be a splintering of the Great Goddess and therefore one and the same with the Mor-rioghan. Brigid exists as a form of the goddess able to survive the transition to Christianity and able to find her own place within Christian mythology as a saint.

The Mor-rioghan

The Mor-rioghan, who is the focus of this study, is a goddess of Irish Celtic mythology appearing in writing no earlier than $876 \mathrm{CE}$ in the Regina No. 215 manuscript, which is actually a gloss of Isaiah $34: 14$. She later appears in full length mythologies such as the Foras Feasa ar Eirinn (The History of Ireland), the "Mythological Cycle" which includes the Cath Mag Tuired (The Battle of Moyturra), a core example of Celtic religion and society, in the "Ulster Cycle" as $\mathrm{Medb}^{3}$, a fiercesome war goddess, in the

\footnotetext{
${ }^{3}$ Queen Medb is another aspect of the Mor-rioghan but differs from her in that she is seen actively engaging on the battlefield, unlike the Mor-rioghan who is never known to do any actual fighting, but
} 
"Fenian Cycle" and in the "Cycles of the Kings", also known as the "Historical Cycles." The Mor-rioghan's name is encountered in several sources as properly being $\mathrm{Anu}^{4}$, who was more than likely a known deity of the indigenous megalithic religion ${ }^{5}$ of Ireland, if only in her role and position she occupied in the society.

Despite the late appearance of writing in Ireland, it is well known that the Irish Celts had developed a hierarchical educational system that began with a required seven years of study in order to reach the first level of Bard, another five to reach Seer, and finally, an additional eight to become a Druid. A Druid would have spent twenty years studying and memorizing not only the religious mythology, but astronomy, law, architecture, astrology, healing arts, and other subjects considered to be of great value and necessary to society. It is accepted then, that the mythology the newly Christianized monks were recording had been in place for hundreds, if not thousands, of years ${ }^{6}$ as an oral tradition.

rather represents war and presides over it, aiding the Tuatha with magic spells against the enemy and reciting poetry as encouragement for her people.

${ }^{4}$ Anu is related to and comes from Danu, the name of the mother goddess of the Tuatha De Danaan. The Tuatha are a mythological race who invaded from the north and were semi-djvine. They were later invaded by the sons of Mil, better known as the Celts. It is believed that the Danube and possibly the river Don in Russia are named after her. Her name is also found in India and whether it is a pre-Vedic or Vedic name raises further questions regarding the spread of Indo-European languages, the Aryan migration, as well as the ethnicity of the Celts whose identity remains a mystery and can only be identified by language.

${ }^{5}$ Little is known about the religion of the indigenous lrish. Our most outstanding clues are the great megalithic cairns, which may have served as burial tombs, ritual places, and/or observatories.

${ }^{6}$ It is impossible to give a firm date to the appearance of a group known as the Celts. Scholars generally agree that there was a cohesive group of people who became known to us as the Celts by at least $500 \mathrm{BCE}$, though many claim much earlier dates and few scholars claim later dates. 
The Mor-rioghan's name is derived from several sources. The first part of her name "mor" means "mare", in reference to both the White Mare and water. The whitewash rolling in from the sea was often referred to as the "white mane of the Morrioghan's head" (Stone, 45). Merlin Stone commented on the similarity between the waters and the mare as important systems of mobility. A similar goddess from India ${ }^{7}$, known as the Submarine Mare, is understood to be a mare that resides in the ocean. Later interpretations relate "mare" to the word "nightmare," in keeping with the patriarchal demotion of the goddess to a fierce and frightful being.

The last part of her name 'rigan' is generally undisputed by scholars as meaning "queen". In the Anglicized version of her name, Morrigan or Morgan, the root 'mor' is still present, and both meanings, sea and mare, probably relate to the Sanskrit word meaning "mighty". "Gan", and its derivations such as gen, and ghan, mean beginning or birth. This becomes clear in the Mor-rioghan's aspect of Anu as the mother of the Tuatha. Sources give the Mor-rioghan's proper name as Anu (from Danu). This infers that she was once the absolute or leading goddess and mother of the Tuatha Dé Danann ${ }^{8}$.

\footnotetext{
${ }^{7}$ Both Ireland and India were eventually either invaded or, as is more likely, experienced long-term migrations of proto-Celts (Indo-Europeans) into their civilizations. Thus, many similarities in names, myths, beliefs, and musical instruments, etc. exist between the two cultures. They have both been sheitered, India by the Himalayas and the ocean, and Ireland by sea, from other surrounding cultures and therefore maintain stronger traces of the ancient religion than do other lands inbetween the two. One example of shared names is the goddess Danu who is the mother goddess of the Tuatha, but she is also found in India as the mother of Vrtra and the demons known as the Danyasas.

' The Tuatha Dé Danann are a mythological race who were thought to be semi-divine. They originated in the north where they had become highly trained in magical arts before arriving in Ireland. They are a preCeltic people whose leading deity was the goddess, Danu. They were eventually driven underground to live in the sidhs by "invading" Celtic tribes and are believed to still walk among the living today.
} 
For the Celts, the Mor-rioghan was related to the earth but her name clearly portrays her as an embodiment of sacred waters as well. Because it is assumed, and probably rightly so, that prehistoric peoples lived in and with nature at a level few people from developed countries can relate to, it has therefore been the trend in both academic thought and in neo-pagan traditions, to attribute ultimate and sacred meanings to the natural elements in the minds of prehistoric peoples. These assignments of the sacred in prehistoric cultures are not without merit, as is seen from the countless ancient mythologies that include water, earth, sun, moon, wind, air and fire gods and goddesses.

In following this line of reasoning, the importance of water as necessary to life would undoubtedly be associated with the goddess, also understood as the giver and sustainer of life. The natural cycles of the tides, which mirrored female menstrual cycles, may also have had influence in connecting water to the female form. Thus women were often linked to the waxing and waning of the moon in early mythologies. We find that water images have frequently been associated with the "nuturing female principle or consciousness" (Knapp, xv).

Water remains one of the most powerful natural forces on the planet. The power and strength of moving water, along with its unpredictability, makes it a dangerous force to be reckoned with. The ability of women to bleed and not die also attested to their power. Both the sea and women may have appeared to be beyond the control of man in their natural cycles and therefore possessed of an inherent freedom which commanded certain respect. As an earth goddess, the Mor-rioghan became more predictable and eventually subject to male domination. Mary Condren points out that once the goddess became related to the land, she became static and unmovable (59). The goddess also 
risked becoming "disposable" as she became less and less important as a figure of divinity and more important in the promotion of "evil", as we shall see.

\section{The Triune Nature of the Mor-rioghan}

Celtic gods and goddesses tend to be triune deities and the Mor-rioghan is no exception. It was believed that only through triplicity can one capture the complexities of the goddess. This was an old but useful idea by the time it was adopted into the Catholic doctrine of the Trinity. The Mor-rioghan is frequently encountered in one of her other incarnations as either Badb, (sometimes called Nemian), or Macha. Other incarnations which do not necessarily represent her triplicity, but more her evolution, are Medb, and Brigid.

Macha is clearly a land goddess, as her name relates to a pasture (O'hOgain, 284). Like the Mor-rioghan, Macha was also associated with horses. It was the great hero, $\underline{\mathrm{Cu}}$ Chulainn, who referred to his horse as "the Grey of Macha" (O'hOgain, 284-5). However, just as "mare" was eventually reinterpreted as "nightmare" from the first part of the Mor-rioghan's name, Macha was later classified as a war goddess as well.

Macha is an important aspect of the goddess in understanding her evolution. Although her name clearly identifies her with the land, most sources describe her as a goddess of war, which appears to be the next step in patriarchal demotion of the goddess. Like her alternate incarnation as the Mor-rioghan, she is related to horses as seen in the Ulster Cycle where she is forced to compete in a race against horses by her husband and the king, despite being nine months pregnant. With her well-known speed, she easily wins, but collapses after the race, placing a curse on all the men of Ulster before dying. 
Her curse caused the men of Ulster to become incapacitated with horrible pain at the time of their greatest need.

Scholars have thought this story to be a survival of an ancient fertility (related to earth) ritual, perhaps even a male practice for transferring the pain of childbirth to themselves'. However, O'hOgain believes the most likely explanation to be that Otherworld women must be feared for their powers to "drain away the strength of warriors" (O'hOgain, 284). This would be consistent with the patriarchal tendency to dismantle goddess theologies by turning a goddess into a fierce, war-like figure who is feared rather than respected. This trajectory was often part of a new cosmology that marginalizes both women and the earth.

As Badb, she can only be related to war. Badb comes from the Celto-Germanic word, "beadu", meaning war or strife. The stories of the hero Cú Cuchlainn's encounters with her are gruesome and horrific. Chulainn finds a beautiful young woman at rivers' edge "lamenting and moaning, washing in cold water purple hacked wounded spoils (weapons)" (O' hOgain, 309). An even bloodier depiction of her has Corman Conn Loingeas finding her at the riverside. This time she is completely red; when she dips her hand into the water, it becomes tainted the color of blood. This sort of imagery was used throughout the Middle Ages in stories of battles (O'hOgain, 309). It is undoubtedly a later addition to her triune nature as is apparent through the linguistic roots of her name.

Unfortunately, there is no way to date when the Mor-rioghan made her transformation from a goddess of the sea to that of the earth. This transformation is undoubtedly a syncretic interpretation of the Irish goddess incorporated into the

\footnotetext{
${ }^{9}$ Sjoestedt has suggested that the imitation of labour pains is a collective rite or symbolic imitation that honours the mother goddess.
} 
patriarchal culture of the Celts who had slowly been migrating to the Island since approximately $500 \mathrm{BCE}$.

Some time before Christianity came to the sacred isle, the Mor-rioghan's favourable attributes were usurped by the goddess Brigid who is often viewed as a "composite" goddess (Condren, 59). After the Christianization of Ireland, around 450 $\mathrm{CE}$, Brigid's name was taken by a convent whose nuns carried out her rituals by keeping a flame burning at all times. The first nun in charge of the convent changed her name and became known as Saint Brigid.

There is also evidence of the Mor-rioghan's further evolution after the time of the great Irish myths. In the south-east of Ireland, the bean si is believed to be an incarnation of the Mor-rioghan, referred to by the name "Badhbh", one of her triune identities. This undoubtedly comes from the story of her "lamenting and moaning" by the riverside since it is the wailing by which one knows the outset of the bean si. In this latest stage of development, she has evolved from a water and earth goddess, in charge of giving and sustaining life, to the source responsible for death, and therefore, something to be feared.

The Devaluation of the Irish Goddess

Domination cosmologies were effectively furthered by the patriarchal nature of Indo-European (hereafter I-E) thought and religion and as this evolution, or as many feminists would say, "devolution", was affected, it found greater or lesser resistance in certain cultures. Ireland proved to be a stronghold of resistance to domination cosmologies, for its goddess was not easily displaced. Her influence remains prominent in the culture today through myths, greetings, saints, and name places. 
The following chart outlines the fundamental changes in the role of the goddess as the focus of the related mythology shifted due to the influence of agrarian culture and the before-mentioned changes that evolved from this pivotal event.

\section{Stages in the Demotion of the Irish Goddess, the Mor-rioghan}

\begin{tabular}{|c|c|c|}
\hline Date & Devaluation techniques & The Role of the Goddess \\
\hline $\begin{array}{l}5,000-1,500 \\
\text { BCE } \\
\text { Neolithic } \\
7,000-2,500 \\
\text { BCE }\end{array}$ & $\begin{array}{l}\text { Migrations of proto Indo- } \\
\text { Europeans to Ireland } \\
\text { (D)Anu - Mother goddess. } \\
\text { In Irish folklore the semi- } \\
\text { divine race of pre-Celtic } \\
\text { people are called the Tuatha } \\
\text { de Danaan or People of Danu. } \\
\text { The Mor-rioghan comes from } \\
\text { this lineage. }\end{array}$ & $\begin{array}{l}\text { Danu was known as a river goddess in } \\
\text { the Sanskrit language; the Don River in } \\
\text { Russia and the Danube are named after } \\
\text { her; she appears as Dānu, mother of the } \\
\text { Dānavas and of Vrtra in the Rg Veda, } \\
12,000-4,000 \text { BCE; Danu is } \\
\text { mentioned as a goddess in the tale of } \\
\text { Gilgamesh, } 2,600 \text { BCE; Homer refers } \\
\text { to the Danaans in the Odyssesy, } 1200 \text { - } \\
700 \text { BCE. }\end{array}$ \\
\hline $4,500 \mathrm{BCE}$ & Agriculture comes to Ireland & $\begin{array}{l}\text { (D)Anu's focus shifts from previous } \\
\text { associations with water to strong } \\
\text { connections with the earth. }\end{array}$ \\
\hline $\begin{array}{l}\text { c. } 3200-800 \\
\text { BCE } \\
\text { Bronze Age } \\
2,500-1,000 \\
\text { BCE }\end{array}$ & $\begin{array}{l}\text { (D)Anu is splintered into } \\
\text { numerous goddesses; the } \\
\text { Mor-rioghan arises. }\end{array}$ & $\begin{array}{l}\text { The Mor-rioghan's proper name is } \\
\text { given as Anu. O'hogain believes that } \\
\text { many other goddesses as well were } \\
\text { derived from the leading mother } \\
\text { goddess figure, (D)Anu, including } \\
\text { Brigid. } \\
\text { The Mor-rioghan appears in writing no } \\
\text { earlier than } 876 \mathrm{CE} \text {. }\end{array}$ \\
\hline $\begin{array}{l}\text { c. } 800 \text { BCE } \\
\text { (though } \\
\text { possibly } \\
\text { earlier)- } 600 \\
\text { CE }\end{array}$ & $\begin{array}{l}\text { Chiefdoms / warrior } \\
\text { aristocracy }\end{array}$ & $\begin{array}{l}\text { The Mor-rioghan becomes honored as } \\
\text { the Goddess of the Land. Warfare } \\
\text { could then be justified to protect the } \\
\text { Goddess who represented the land. } \\
\text { The Neolithic and Bronze Ages appear } \\
\text { to have been fairly peaceful with no } \\
\text { defensive structures from the Neolithic } \\
\text { and few weapons from the Bronze. } \\
\text { However, the Iron Age gave birth to } \\
\text { stockpiles of weapons and chiefdoms } \\
\text { were well organized. }\end{array}$ \\
\hline
\end{tabular}




\begin{tabular}{|c|c|c|}
\hline $\begin{array}{l}\text { c. } 800 \mathrm{BCE}- \\
600 \mathrm{CE}\end{array}$ & Militarization & $\begin{array}{l}\text { As representative of sovereign lands, } \\
\text { the Mor-rioghan is depicted as a } \\
\text { powerful element in battle, capable of } \\
\text { awarding victory or defeat to the army } \\
\text { of her choice. However, her } \\
\text { participation in warfare lowers her to } \\
\text { the level of human strife. She suffers } \\
\text { even further moral demotion through } \\
\text { connection to the inevitable } \\
\text { consequences of warfare, i.e. torture, } \\
\text { suffering, death, etc. }\end{array}$ \\
\hline $\begin{array}{l}\text { c. } 600 \mathrm{CE} \\
\text { (no firm date } \\
\text { for the birth } \\
\text { of banshee } \\
\text { lore has yet } \\
\text { been } \\
\text { identified) }\end{array}$ & Banshee (Bean si) & $\begin{array}{l}\text { Badb, a trinitarian aspect of the Mor- } \\
\text { rioghan, takes on the new role of } \\
\text { supernatural death messenger. She } \\
\text { heralds the passing of life but has no } \\
\text { other power. She is neutral, neither } \\
\text { good or evil (though occasionally } \\
\text { considered evil within a Catholic } \\
\text { context, as any foreign spirit might be) } \\
\text { and relegated to "ghost" rather than } \\
\text { goddess. }\end{array}$ \\
\hline $500-700 \mathrm{CE}$ & $\begin{array}{l}\text { Other aspects of the Mor- } \\
\text { rioghan absorbed by Christian } \\
\text { female figures }\end{array}$ & $\begin{array}{l}\text { Brigid, one of the later aspects of the } \\
\text { Mor-rioghan, was, after the coming of } \\
\text { Christianity to Ireland about } 500 \text { CE, } \\
\text { transformed to major saint, said to have } \\
\text { been present at the birth of Jesus as } \\
\text { midwife. In other sources Brigid was } \\
\text { considered the "Irish Mary." }\end{array}$ \\
\hline
\end{tabular}

While the Mor-rioghan is the subject of this study, her roots go back as far as can be ascertained as the mother goddess figure, (D)Anu. While no definitive description of her role or the position of women in such societies can be determined, the wide usage of her name and the naming of key rivers after her seems to indicate some degree of importance or affinity for her. (D)Anu becomes associated with the land as agriculture becomes the way of life. This was undoubtedly an honored position that came, probably 
in great part, through the goddess's obvious intimate knowledge and representation of fertility through pregnancy and childbirth.

Unfortunately, with the passing of time, the land goddess seems to have become somewhat static and a need for goddesses in different areas led, again in part, to her being splintered into many forms. The effect of splintering the leading 'Mother Goddess' figure will be explored in subsequent chapters. In brief, it should suffice to say that the splintering weakened her overall position leading, in Ireland, to her role as sovereignty goddess and her eventual militarization, all of which were undoubtedly understood as honored positions at the time of their creation, but which could not endure in the face of new developments in culture and religion. Within the new religion of Christianity, the Mor-rioghan was transformed into the bean si, where she becomes little more than a ghost; a frightful spirit that heralds death rather than an empowering figure of ultimate importance. In her aspect of Brigid she is able to find a place in Christianity that affords her some importance. The catalysts for the evolving mythologies and the various interpretations will be discussed in the following chapters. 


\section{CHAPTER TWO \\ THE GODDESS OF MATRISTIC CULTURE}

Marija Gimbutas has been one of the leading advocates of a goddess-centered religion in prehistory. She recorded the unearthing of hundreds of small feminine statues at Catal Huyuk, on Crete, in Turkey, as well as several other sites. In Ireland, where the early Irish were either not inspired to re-create the feminine form three dimensionally, or lacked the means, Gimbutas interpreted burial patterns and the various geometric patterns found inside the great megaliths and on the surrounding orthostats as female-related. This chapter examines Gimbutas's interpretation of pre-agrarian goddess-centered civilizations throughout Europe including her analysis of the Mor-rioghan in lreland. After establishing a basic worldview of pre-agrarian and early agrarian civilizations and the earliest role of the Mor-rioghan in this chapter, the aspects of demotion of the goddess can be traced in their unconscious unfolding through developing mythologies in subsequent chapters.

Eller deconstructs the work of Gimbutas in her book "The Myth of a Matriarchal Prehistory; Why an Invented Past Won't Give Women a Future". In her work, Eller calls into question the idea of a once peaceful, matri-centered, goddess-worshipping society, a favourite theory of feminists whom she refers to as "matriarchalists". She believes there is a significant lack of evidence regarding such cultures and believes, given historic trends and paradigms, that the existence of prehistoric peaceful, female worshipping 
societies is an improbability 10 . The "matriarchalists" have largely built their theories off the foundation laid by Marija Gimbutas who unearthed numerous female figurines in her research and came to believe that the goddess must have occupied a significant, if not dominant, position in prehistoric cultures. However, the writings of the popular feminist "matriarchalists" that Eller is so vehemently opposed to do not include Gimbutas but came after her. These later writers who openly cite Gimbutas's work as evidence of a matriarchal prehistory tar her writings and cause Eller to misplace her frustration.

Despite this confusion, Eller maintains there are weaknesses in Gimbutas's findings of goddess figurines, unfortified cities, lack of weapons, lack of inequality in grave goods between men and women and social classes, and pictures of goddesses and people involved in activities such as play rather than war. Eller provides research from additional archaeologists who believe there were fortifications at the sites Gimbutas excavated. She sees the lack of violent deaths, mass graves, and other typical signs of a warring culture as no reason to assume these were peaceful civilizations. In citing Marvin Harris she raises the possibility that the cultures in question may indeed have been engaging regularly in warfare, just that they did so elsewhere rather than on their own territory. Eller points out that what feminist matriarchalists most want to find is the absence of iniquities such as sexism, racism, violence, and war, which plague modern society and are often attributed to patriarchy. She admits that it is harder to prove the absence of something than its presence:

Digging up comfortable homes, material prosperity, even bodies free of disease or spared untimely death (all things we might reasonably

\footnotetext{
${ }^{10}$ Refer to "The Myth of Matriarchal Prehistory" by Cynthia Eller, 2000 for a fuller discussion of prehistorical patriarchy versus matriarchy.
} 
want) still does not mean that we have excavated a society free of sexual oppression (Eller 2000, I I5).

Despite the skeptical analysis of theories regarding a matriarchal prehistory, most scholars accept the evidence relating to the existence of goddesses who served as important figures of divinity in religious pantheons throughout the world. Goddess figures and stories not only existed, but proliferated until the early middle ages when they were suppressed and the last of the goddess temples, at least in Europe and the middle east, were destroyed.

\section{Gimbutas's Research}

Based on Gimbutas's archaeological discoveries of hundreds of small feminine statues and analysis of burial patterns, she believed that European prehistory, or "Old Europe $^{11 ",}$ was made up of matristic societies. Gimbutas's research and analysis of the feminine figurines she unearthed led her to conclude that they were representations of goddesses, of which earth fertility was but one aspect. She recovered feminine figurines from temple altars, oven platforms, in offering places, caves, and graves. There were also male figurines, which constituted about three to five percent of the corpus of sculptures recovered (223). She believed that the figurines as a whole represented "a Goddess who is ultimately Nature herself'(223). Miriam Robbins Dexter points out that this goddess is often misunderstood as being a monolithic deity rather than a multidimensional representation of divinity. Gimbutas herself breaks the Goddess down into four major categories; a personification of the generative abilities inherent in nature, the

\footnotetext{
II "Old Europe" was the term Gimbutas assigned to the pre-indo-European cultures that she believed to be matrilineal and matriarchal and who were later overthrown by patriarchal Indo-European civilization.
} 
Death Goddess, the Goddess of Regeneration ${ }^{12}$, and the various male deities. The Goddess then, embodies both male and female characteristics and could be seen as androgynous where appropriate.

While earlier male archaeologists had dismissed the figures as pornography, Gimbutas discounted the possibility of prehistoric pornography, instead pointing out that these naked bodies, whether male or female, lacked any signs of unnaturalness, sinfulness, or obscenity. Gimbutas herself remarks that regarding the figurines solely as pornography represents a male bias present in contemporary culture while ignoring the apparent religious and social functions of the statues. From the unearthed figurines, such as in the common female statue with large buttocks and often an enlarged vulva, Gimbutas deciphered meaning: the sacrality of life. She proposed that these figures represented sustenance to the Neolithic culture (Gimbutas 2001, 7).

In examining burial patterns at Catal Huyuk, Gimbutas found one woman buried beneath the floor of the temple with elaborate grave goods. She also found other older women and girls buried under floors, near houses, or under long earthen mounds with rich grave goods. In contrast, she found no male graves with symbolic or ritual grave goods. Gimbutas was able to link the symbol of the bull with the Goddess of Regeneration and she found at Lepenski Vir, along the Danube in Yugoslavia, that burials occurred in temples, which appeared to be dedicated to the Goddess of Regeneration. In Crete she discovered egalitarian communal burial tombs that seemed to

\footnotetext{
${ }^{12}$ The Goddess of Regeneration differs from the first category, a personification of the generative abilities inherent in nature, in her focus on controlling the life cycles of the entire world. Gimbutas believed this aspect of the goddess's symbols to be the uterus, pubic triangle, fetus, etc. The first aspect of the Goddess seems to represent the role of sustainer, or the ability of life to regenerate and sustain itself as a whole, whereas the Goddess of Regeneration focuses more specifically on reproduction.
} 
show no social or religious distinction between male and female members of extended families. Throughout the Aegean and Mediterranean burials included one to three stiff nude female figurines buried in graves, which she believed represented the tomb goddess. Other evidence such as the lack of numerous violent deaths, weapons, and unfortified cities were key elements in supporting the idea of prehistoric matristic cultures for Gimbutas, which was a much bolder statement than that of simply a matriarchal one. A matristic culture included a female figure who was not only the head of the housebold, as in a matriarchal family, but also through whom descendents could be traced. In the case of Gimbutas, and the many scholars that followed after her, these early matristic cultures relied greatly on a female deity and the teachings that grew out of goddess lore.

Other archaeologists besides Gimbutas have found some of the same striking features of these early civilizations, namely the absence of city fortifications. Sir Arthur Evans, who excavated Crete came to the conclusion that the Minoan civilization of Crete (2,000 B.C.E. to 1450 B.C.E $)^{13}$ must have lived in relative peace. There was no evidence of defensive walls. Gimbutas looked at the art and found evidence of festivals, religious rituals, and play, but nothing that looked like war or the spoils of war were depicted in drawings. Additionally, she found no evidence of weapons, except those necessary for hunting and eating, among grave goods in Europe until 4500 B.C.E., the date she

\footnotetext{
${ }^{13}$ Agricultural communities were present on Crete as early as 6,000 B.C.E., but it did not attain "city" status until 2,000 B.C.E. when there was evidence of cities and religious centers. In 1628 a nearby volcano erupted on the island of Thera, destroying much of Crete's northern shores. However, the civilization persisted until 1450 B.C.E. when it appears to have been invaded by Indo-European with burning and destruction evident. The golden age of Minoan civilization is generally regarded to be between 1700 and 1450 B.C.E.
} 
identifies as the first wave of Kurgan expansion. The Kurgans did not reach Crete until 1450 B.C.E.

Through extensive excavation and research, Gimbutas reconstructed a prepatriarchal 'golden age' for women in which the goddess was the center of worship and women were valued, if not deified, members of society, resulting in a more or less egalitarian existence for men and women. During this age, she speculated that women were free from male oppression, they experienced sexual freedom, and both genders benefited from a peaceful, harmonious society that treated the earth with respect and maintained natural resources. This has been the general picture assumed to be related to a matristic culture, while current patristic societies reflect much of the opposite: sexual oppression of women, slavery, warfare, depletion of natural resources and societies full of crime and violence.

In reconstructing the religion of the Goddess, Gimbutas posited a balanced theology that included a goddess who personified the generative forces of nature and a goddess who personified destructive forces of nature (Gimbutas 1991, 223). The religion of the Goddess was one that revered life and so the life-giver in human female form was accorded great reverence. Many scholars have since renounced this theory as relatively unfounded, but agree that matrilineal descent is still a possibility. Engels felt confident that "mother-right" was indeed the cultural norm and believed it to be "more than sufficiently proved by the abundant traces of mother right which have been collected, particularly by Bachofen" (86). 
According to Gimbutas, around 4500 B.C.E., a culture from the Steppes of Russia, known as the Kurgans ${ }^{14}$, began a series of three migrations ${ }^{15}$ and /or invasions into the Near and Middle East which eventually spread at least as far as India and Ireland in either direction and as far south as Italy. While these invasions are not the birth of patriarchy, since the Kurgan culture already subscribed to this cultural misfortune, their migration does represent the spread of patriarchy and the demise of peaceful matristic societies ${ }^{16}$ and inevitably, the goddess.

Eller, who finds it difficult to subscribe to any of the "matriarchal" theories, admits that there is substantial archaeological, linguistic and genetic evidence for a spread of northern peoples around the fourth and fifth millennium. However, she points out that this should not necessarily be considered the birth of patriarchy since she dismisses Gimbutas's interpretation of archaeological evidence and insists we do not know how the southern communities, into which the proto-Indo-Europeans disseminated, were organized (Eller, 2000, 179). She explains that much of the belief that pre-historic society was communistic and egalitarian is based on those tribes or cultures that exist

\footnotetext{
14 "Kurgans" is the name Marija Gimbutas gave to the invading patristic culture of the Russian Steppes. The Sredny Stog culture (4500-3500 B.C.E.) was found in the Southem Ukraine and from this culture emerged the Yamnaya culture (3600-2200 B.C.E.), which spread from the Danube to the Volga Rivers and beyond. Both the domestication of the horse and the invention of wheeled vehicles are attributed to this culture.

${ }^{15}$ The first wave occurred between 4400 and 4300 B.C.E. The graves of these first Kurgans showed a completely different ideaological culture. Gimbutas found no fernale graves and the first signs of sati (the wife being burned alive on the funeral pyre of her husband). The second wave was around 3500 B.C.E. With this wave the hierarchical and patriarchal culture of the Kurgans transformed Europe, wiping out previously still-existing remnants of matriarchal/matristic culture. The third wave is dated at 3000 B.C.E. and is a group known as the Yamna from southem Russia. This is the group that developed into the protoIndo-European, later the Indo-European, and finally a splinter group known as the Celts.

${ }^{16}$ Gimbutas' claim that prehistoric cultures were peaceful and that the only weapons present were those used exclusively for hunting has been widely criticized. Numerous archaeologists have found evidence of injuries and deaths incurred by arrows and similar sharp weapons.
} 
today with little, if any, contact with industrialized societies. The presence of mysticism and a belief in beneficial spirits seems to have played a role in the development or maintenance of such cultures. Alice and Irvin Child found that mystical power was prevalent in these cultures whose economy was still based on hunting and gathering. Supporting research shows that such cultures emphasize self-reliance and are therefore relatively egalitarian (Child 21). The researchers point out that if

a person's power comes from a direct relationship with a guardian spirit [it is possible] that any member of a society might establish such a relationship and receive a gain of mystical power. It is understandable then, that such a belief is more likely to be found in relatively egalitarian societies. Foragers are especially likely to be egalitarian, with little variation in status among members (23).

Sanday reached the same conclusions of egalitarianism in her research.

Gimbutas has had to face criticism primarily regarding her interpretation of the artifacts, which she generally understood to fulfill a solely religious function in a goddess worshipping culture. She has identified both male and female figurines; however some scholars feel some of her female figurines are of a doubtful gender, and believe Gimbutas has uncritically identified them as female. Some archaeologists and scholars also criticize her for not taking into consideration those items that may have served a purely functional use rather than a ritual one. Failure to exclude figurines where the context in which the figurines was not preserved has also been a common criticism of her work. Without context, the argument for or against the nature and meaning of the artifact is significantly weakened.

Ultimately, whether or not a matristic culture ever existed, and whether or not it was egalitarian or just as destructive as patriarchy, cannot be determined. However, the 
past Gimbutas has created for women, though it may or may not have ever existed, has had an empowering effect on many of the women interested in her writings. Her research engendered a deluge of goddess-centered literature, both popular and scholarly, that explored the possibility of a matrilineal matriarchy and what the consequences of such a society may have been. In this respect, Gimbutas was a forerunner in feminist thought, though she never considered herself a feminist. Despite the criticisms, her work holds great significance by developing one of the first theories regarding a goddessworshipping Neolithic culture.

Countless books from numerous feminists and thealogians have emerged based on this theory of the once peaceful, matri-centered society, and as Eller mentioned in her book, Living in the Lap of the Goddess, theories of the birth of patriarchy are both multitudinous and creative, ranging from the normative, theories of a gradual shift from matrilineal to patrilineal societies, to proposing that men are in fact aliens who invaded a peaceful, woman populated earth bringing hostility and discontent (Eller 1993, 164). In general, thealogians see their work regarding the goddess as enlightening, positive, and much needed, not only for women, but for the earth as well.

The basic theory that thealogians after Gimbutas have most often employed is the theory of the invading northern culture of patristic Indo or proto Indo-Europeans who violently overthrow more southern, matristic cultures. ${ }^{17}$ However, most scholars now agree that while warfare was certainly present, the spread of I-E culture was, in most cases, the result of a general dissemination and intermarriage into other cultures. The "invasion" theory is quickly being displaced by the "migration" theory with warfare

\footnotetext{
${ }^{17}$ Refer to Eller 2000 for a complete history of various matriarchal theories and their beginnings.
} 
largely attributed to growing populations that caused otherwise distant communities to come into closer contact with one another and eventually clash over resources.

Past work has also focused on identifying the miscreant group or cultural idiom that initiated patriarchy and the abuses that stem from it. However, some scholars now see this as irrelevant. Religion scholar Rita Gross believes it is not only counterproductive for scholars to attempt to isolate the cause of patriarchy, but it actually hinders efforts at dismantling the destructive cycle. She sees the inevitable conclusion as a moral debate between women and men in which men will ultimately be characterized by women as morally deficient and prone to violence. If this is the final outcome, it becomes highly unlikely, if not impossible, to move beyond patriarchy since men, due to their flawed morality, will be excused from their misdeeds and deemed incapable of more sophisticated and egalitarian means of living (83).

When, and if, society can move into a post-patriarchal phase, Gross finds it likely that the symbols and ideologies will resemble those of a pre-patriarchal culture. The new symbols will have to represent gender equality and will likely include symbols of female sacrality (86). However, she cautions against the veneration of the "mother" symbol:

...female forms and symbols [that] stress their fertility and maternity, [are] by no means a sufficient meaning for female sacrality in today's religious universe. While valorizing motherhood is an important issue in contemporary feminist religious reconstruction, not privileging that symbol is absolutely vital, even mandatory, for human survival. Considering that increased maternity, resulting in increased population density and competition for scarce resources, is probably one of the causes of patriarchy, feminists should be loathe to enshrine physical reproduction as the primary symbol of female sacredness" (88). 
The Mor-rioghan, like most Irish goddesses, has little, if anything, to do with emulating the reproductive capacity of women. In their triplicate form, the Irish goddesses do reflect the life, death, and re-birth process. However, this is understood in terms of the overall experience by which the soul, male or female, is transformed, rather than the narrow range of value often placed on women as "baby-makers" who have, at least in Christian doctrine, little value beyond that.

This is not to say that some goddesses are not more closely connected with concepts of fertility, as in the case of Brigid, who is clearly associated with Imbolg ${ }^{18}$. However, no weight is placed on her ability to conceive as an individual, but rather on her having the power to regenerate and produce new crops that will sustain the people. Fertility, while symbolized by the female image, is conceived of in terms of life-sustaining abilities that benefit both men and women. There are no images of pregnant goddesses from Ireland, either twodimensional or three. In this respect, the Mor-rioghan, as well as other Irish goddesses, may provide a positive image that could be re-used in the struggle to develop a system of egalitarian sustainability.

Gross's analysis of the problems associated with the pregnant goddess, a symbol of womanhood which was so hailed in the work of Gimbutas, shows an evolving awareness that one must be careful when creating new symbols. Other scholars have chosen to evaluate current feminine archetypes, namely those from within Judeo-Christian mythologies. Within this context, feminist theologians

\footnotetext{
${ }^{18}$ Imbolg, spelled variously as Imbolc, Oi-melc, Oimelg, is one of the cross-quarter days between the solstices and equinoxes and falls on February 1 and 2 and is the beginning of spring, a time generally connected with fertility, especially among livestock.
} 
have generally found insufficient role models for women. Those that do exist often do so because they somehow serve the needs of the men in the myth, as in the case of the Virgin Mary.

Mary is generally considered to be a weak substitute, or reincarnation, of the early goddesses, though Christians are quick to point out that the veneration of Mary has nothing in common with that of the Great Goddess of pagan religions. Mary Daly, who has been one of the most vociferous in her condemnation of the "male-only" god, points out that women have been offered Mary as a sort of compensatory glory (Daly, 81). The only real value Mary has, according to Daly, is in her connection to a man, in this case, as the mother of Jesus. Without this, she lacks any defining "greatness" of her own.

Rejecting Mary, then, as a suitable and empowering "goddess" figure, Daly is forced to re-create the meaning of the early Goddess. She sees the symbol of the Great Goddess as "the key to salvation from servitude to structures that obstruct human becoming" (Daly, 96). In other words, the way to reclaim, or liberate the world, women, and those considered to be "other," is through the Goddess. For Daly, as well as many others, the Goddess has come to represent a time before the enslavement of patriarchy, whether there ever was such a time or not.

As we have seen, the theories of a non-patriarchal pre-history, ones that were gyno-centered, are not without their critics. Eller has produced extensive arguments for the absence of a matriarchal, and perhaps even goddess-centered "golden age" in her book The Myth of Matriarchal Prehistory. She details the 
problems with many of the theories and re-examines the archaeological evidence and its past interpretations. She also critiques, and largely rejects, the possibility of a "patriarchal revolution" and the idea of a northern invasion. Although she admits that some of the theories represent plausible explanations of the data collected, she ultimately rejects the gynocentric theory as well, since there is no way to reach clarity about possible pre-historic sexism and gender issues. Her argument appears to rely strictly on written texts as the only reliable source of information about the past. It dismisses all other artifacts, such as grave goods, burial patterns, ritual items, drawings, temples, palaces, etc. as invalid and rejects intelligent formulations of well researched theories. Nor does it take into consideration the forgery and deception found also in written forms of evidence or the bias that can distort interpretation of texts. No artifact is self-explanatory.

Additionally, Eller points out that the myth of what she calls "matriarchal" prehistory closely mirrors the Judeo-Christian creation stories, suggesting its utility in providing women with a "myth" that feels familiar and can therefore be readily accepted. For her, the theory of a matriarchal pre-history is as patriarchal a conception as the patriarchal religions women are currently trapped in. One wonders whether Eller gives women sufficient credit to be able to think outside hierarchical structures or whether the human species is so firmly entrenched in androcentric philosophies and religions that there is no hope for the integration of women and men as the androgynous personalities Mary Daly hoped for. 


\section{Demotion of the Goddess}

One thing that Eller does not reject, of course, is the secondary status that has been afforded women, at least since the historical era. She makes it very clear that under patriarchy, women have been victims. As mentioned earlier, there is no doubt that goddesses existed, proliferated, were venerated, and played an active part in early cosmologies. Whether or not they were venerated to the level proposed by Gimbutas and other thealogians as the god-head of matristic societies with men as the secondary sex is irrelevant when faced with the question of why and how the goddess disappeared. It is indisputable that in western culture and much of the near east, the goddesses have been replaced by a singular male god. Most matriarchal and matri-centered theories would forward the idea that the goddess was the victim of a violent overthrow or several waves of violent invasions, usually conceived of in terms of a quick invasion and replacement of inatriarchal mythos with a patriarchal one. However, it is unlikely that the mythologies changed very quickly. Instead, the mythologies experienced a slow and gradual evolution, including accounts of matricide and the birth of patriarchy.

Ireland is a classic example of this. The Irish have been very slow to change religiously and have managed to retain the goddess in various ways. This is apparent when traveling the countryside and even through the cities. The landscape, both urban and rural, is dotted with elaborate shrines, not one in honor of a male deity, but rather to Mary or the old goddesses, most often Brigid. The hills and cities are named for the goddesses; escaping their presence is nearly impossible. Historians note that the Irish would not convert to Christianity unless 
they could have Mary. As early as the $13^{\text {th }}$ century there were at least fifty-one churches and monasteries in Ireland that were dedicated to Mary (Joyce 91).

Despite the Irish love of the goddess and her longstanding influence, her decline seemed inevitable in the face of developing androcentric theologies. Leading theories for devaluation include: the splintering of one major deity into many, demotion to secondary status as wife or daughter to a leading male deity, further demotion through militarization, continued vilification by linking the goddess with undesirable attributes such as death, murder, torture, warfare, etc., and in Judeo-Christianity, assigning her responsibility for the fall of humankind. In the final phase, as seen in the shift from Goddess to Christian Mary, the goddess (and by implication all women) is found to be not only lacking in power, but unable through her own natural procreative abilities to be the mother of a god without special intervention. Christian dogma of the Immaculate Conception teaches that Mary not only conceived Jesus without sin, but was herself conceived without sin, unlike normal humans. The vilification of women and women's bodies reaches absurd proportions in the Christian myths and continues onward to vilification of the earth by church theologians ${ }^{19}$.

Whether these myths of demotion were created out of fear of woman's powers, or as a continuing attempt to erase all concepts and ideas that related even

\footnotetext{
${ }^{19}$ Augustine, Aquinas, Tertullian, as well as others, wrote prolifically in regards to women's status as the "second sex." Augustine came to the conclusion that the only possible reason for the existence of women was for procreation and considered them nothing more than the vessel for carrying the man's child. Borrowing from Aristotle, he considered female children to be "malformed males." This same vilification occurred with respect to how nature was viewed. Nature was equated with the feminine. Like woman, it was not in God's image and was therefore not divine. According to early church theologians, nature was something to use, abuse, and distance oneself from in an effort to become closer to God.
} 
remotely to pagan myths, is, of course, unknown. A combination of both may have been at work in the development of these myths. Women were already an oppressed class in most parts of the world by the time of the Judeo-Christian mythology, leading one to surmise that the development of these myths may have been an attempt to justify woman's lowly and oppressed position by making it divine will. It was obvious then that the goddess was no longer necessary in this tradition. The only significance a woman, goddess or otherwise, could hold was in their relationship to a man or male deity. They lacked the ability to represent value in and of themselves.

\section{The Mor-rioghan and Gimbutas}

According to Gimbutas, by the time of the Celts, the Kurgan expansion had converted most of Europe to its patriarchal ways, valuing strength and skill in warfare over peaceful goddess worship. The Kurgans, a proto-Indo-European culture, spread either by slow migrations and intermarriage and/or invasion and slavery of indigenous cultures. Gimbutas proposed that the Celts, their origins still largely considered a mystery, formed from the meeting of Indo-European and Old European cultures sometime around the $7^{\text {th }}$ and $8^{\text {th }}$ centuries B.C.E. They quickly invaded most of Europe from Ireland down into Greece and Italy and eastward through Turkey, possibly migrating as far as India. They were slowly driven back into what is often considered the Celtic lands today of Ireland, Wales, and Scotland.

In the Mor-rioghan, Gimbutas perceives remnants of the Neolithic bird goddess. She speculated that in the Neolithic religious imagination birds represented "health, 
fertility, and good fortune" (Gimbutas, 14). Due to the countless creation mythologies connected to eggs and the migratory nature of birds disappearing in the winter and reappearing in spring, the bird came to be a symbol of life, sustenance, and hope. Of course, not all birds represented life. That which represents life and sustenance is just as often an agent of cosmic balance, able to remove life from its known material reality. This concept was represented by birds of prey such as vultures, crows, and owls.

In Irish mythology, the crow is a symbol of impending death, and as a shapeshifter, the Mor-rioghan most often appears in the form of a crow. In this aspect, she is a messenger of death. When she is not appearing in one of her various animal forms, she is generally using magic to hinder enemy armies, ${ }^{20}$ thus acting as an agent of bloodshed and warfare. Epstien noted in her dissertation that by the ninth century, the term morrigan had come to denote "a monster in female form." Another early reference to her uses the term "guidemain" which means demons of the air, clarifying that the class of demons referred to by the term morrigna $a^{22}$ was not to be associated with demons of hell, but with the badb or hooded crow.

There is some evidence that in the early historical era $^{23}$ of lreland, the Morrioghan may also have been equated with the screech owl. A codex written around 876 C.E. contains the Regina No. 215 manuscript, which identifies the term Lamia as an

\footnotetext{
${ }^{20}$ In the first battle of Mag Tuired, the Mor-rioghan acts with her Trinitarian features, Macha and Badb, to "terrify the enemy with magic showers of fire, mist, and blood" (Gray 130).

21 The phrase, "monstrum in femine figura .i. morrigain" is found in the Regina No. 215 gloss of Isaiah.

22 "Morrigna" refers to a special class of winged demons. This interpretation comes from the historical era, much later than the creation of the myths (Epstien 31 ).

${ }^{23}$ The historical era begins with the Christianization of the Island around 450 C.E.
} 
equivalent of morrigna (Epstein). Lamia was translated as screech owl and identified with Lilith ${ }^{24}$ in the Old Testament.

Gimbutas proposes that such birds of prey as the crow and screech owl represented the goddess of Death. The basic nature of the bird goddess was dual in nature, representing the "giver of life, well-being, and nourishment. On the other hand, she also appears as Death in the guise of a vulture, owl, or other bird of prey or carrion eater" (Gimbutas 230). Gimbutas found numerous Neolithic depictions and carvings of owls throughout the Celtic lands. In Ireland and Brittany, owl figures had what Gimbutas believed to be a vulva in the center (Gimbutas, 20). The most apparent association of birds of prey is with death as they hover over dead animals and pick their bones clean; however, the presence of the vulva on the owls seems to represent the idea of a necessary balance in the universe between life and death.

All life in nature proceeds from death, as death from life. . The acknowledgment of this interdependence and continuum between life and death is expressed in prehistoric mythologies as the Mystery at the core of all being. It is no wonder that the lives of ancient peoples seem to have pivoted around seasonal observations of death and regeneration (Gimbutas 243).

Gimbutas believed that exposing the dead, or excarnation, may have been a primary form of taking care of bodies. This entailed little work on the part of the living other than exposing the bodies so the bones could be picked clean by birds of prey. Thus follows the obvious connection of the bird goddess in her bird of prey form as the Goddess of Death.

\footnotetext{
${ }^{24}$ Lilith, the first partner of Adam in the Garden of Eden, was quickly demoted to a monster that kills small children after refusing to have intercourse with him. Bitter at having been kicked out of the Garden, she sought revenge by attempting to take the lives of other women's children. The patriarchal mythology of Lilith should be considered in its own right.
} 
This method was practiced throughout Europe, including Ireland. In many of the great megaliths of Ireland, such as Newgrange, ${ }^{25}$ bones were interred in the great mounds after first having been defleshed. It is often speculated, due to the window box structure $^{26}$ of Newgrange, that the Neolithic people believed the souls of the people interred would transmigrate, presumably at the winter solstice. There is some evidence suggesting that people were temporarily buried elsewhere before being defleshed and placed in the passage tomb (O'Kelly, 105). Three persons' remains found at Newgrange had been cremated while two others had not been. The method of de-fleshing the two uncremated people is unknown. It is possible they were exposed or buried, or a combination of both. Newgrange is said to be home to the Dagda, or leading male deity in Celtic legend, who had at one time the Mor-rioghan as his wife. There are two hills near Newgrange which are dedicated to her. In this way, Newgrange maintains ties to the Celtic goddess who Gimbutas saw as having an aspect of the Goddess of Death in her persona.

Carved into many of the great orthostats, both inside and surrounding the megaliths, are geometric shapes that have been the fodder of much scholarly (and not so

\footnotetext{
${ }^{25}$ Newgrange is a megalitbic structure whose actual purpose is unkown, although it is largely thought to have been a passage to the otherworld in Celtic mythology. It has been dated to 3200 B.C.E. and is between 10.9 and 13.4 meters high with a NW to SE diameter of 78.6 meters and NE to SW djameter of 85.3 meters. Burials have taken place in this particular megalith, though many scholars refuse to identify all Irish megaliths as graves since other nearby cairns, such as the one at Loughcrew, show signs of being an observatory or having ritual use.
}

${ }^{26}$ Above the doorway of Newgrange is a window structure that is aligned with the winter solstice dawn. Between the $19^{\text {th }}$ and $23^{\text {rd }}$ of December, the sun's rays penetrate the 19 meter passage allowing 17 minutes (an auspicious number in both Hindu and Celtic mythology) of light to reach the back of the chamber. 
scholarly) speculation. ${ }^{27}$ Gimbutas believes several basic symbols found among both insular and continental Celts to be symbols of the bird goddess. She found chevrons and V's engraved and/or painted on objects believed to have been used in the worship of the bird goddess (Gimbutas 45). Spirals, zigzags, and wavy lines she believed to be associated with the snake goddess. ${ }^{28}$ The basic forms found amongst Irish megalithic structures tend to be chevrons, spirals, zigzags, arcs, circles, and dots. ${ }^{29}$

While any definitive answer can probably never be ascertained from the megalithic carvings in relation to representing a goddess or otherwise, early references to the Mor-rioghan do support her relationship to the crow or "winged demons". From this early information, it appears that Gimbutas was correct in associating the Mor-rioghan with a Neolithic bird divinity. However, the written references to the Mor-rioghan began quite late in her history at $876 \mathrm{C}$.E., by which time Christianity was already well established. The reason for Christian monks recording the old pagan myths has generally been credited to a general appreciation for their heritage and desire to preserve it. Some have declared that it was Christianity that brought knowledge of reading of writing. However, it should be noted that St. Patrick is said to have destroyed thousands of written

\footnotetext{
${ }^{27}$ Because the engravings are of varying abilities, Claire O'Kelly believes that it was the engraving itself that was the ritual. N.L Thomas believes the carvings to represent various cosmic events, such as dawn, the equinox, new moon, and the months of the year. Astroarchaeologists believe certain carvings to be maps of the cosmos.

${ }^{28}$ It is highly unlikely that snake goddesses or gods held a position of much importance among the indigenous Irish. The only native reptile is the common lizard, lacerta vivipara, and only in recent years have there been sightings of "snakes" which upon further investigation, have been identified as legless lizards, anguis fragilis, or slow worms.
}

${ }^{29}$ For a listing and analysis of the geometric shapes, consult O'Kelly. 
manuscripts of pagan origin. The monks may have been re-copying those tales that had been lost, albeit with some Christian influence.

Ireland had proven to be a tolerant place. The early inhabitants had incorporated the Celts into their presumably goddess-worshipping culture, developing a syncretic, yet largely patriarchal religion. The spread of Christianity in 400 C.E. was also endured with grace. The first step was the conversion of the King's druid, ${ }^{30}$ which resulted in yet another syncretic religion that looked something like orthodox Christianity, but followed in the footsteps of the Egyptian desert ascetics, and incorporated the old gods and goddesses by turning them into saints. This new religion ${ }^{31}$ represented the culmination of patriarchal thought and belief in Ireland.

The Mor-rioghan had been evolving through major social and religious changes for hundreds of years before the myths were written down by monks of the new religion. From her etymology, it seems clear that she was originally conceived as a water divinity. She was, Danu, a semi-divine representation of the sacred waters of the Danube, and possibly the river Don. But she also represented balance, at least to the Celts, as seen in her form of the crow, a bird of prey. However, in no way does her early etymology seem to connect her to warfare. It is likely that her trinitarian aspect of badb, who heralds

\footnotetext{
${ }^{30}$ Each year at Beltaine, (May 1) the High King lit the ritual fire on the Hill of Tara. In 433, St. Patrick climbed the neighboring hill of Slane and lit a fire before the High King could. The King remarked that if the fire (Christianity) were not immediately extinguished, it would bum forever. In the following confrontation, the King's Druid converted to Christianity. The King, who was either unable or unwilling to argue with his Druid (Druids were highly respected, but also feared for their magical abilities) proclaimed Christianity the new religion. While this is largely considered a legendary tale, the year that Easter was first celebrated and presided over by St. Patrick is recorded by Muirchu in his manuscript, "The life of St. Patrick", written sometime between 680 and 700 .

31 The new religion was Christianity, but it would not take a truly recognizable Roman Catholic form until approximately 1200 after the synods at Cashel in 1101, Rath Bresail in 1110, and Kells in 1152 . The monastic church of Ireland was replaced by two archbishoprics, one in Armagh and the other in Cashel, that were subject to the bishop of Rome. The Irish church began to take on the more formal governing characteristics of its neighboring continental churches, which had long been under the authority of Rome.
} 
eminent death and strikes terror into the hearts of men on a battlefield, is a later addition, perhaps replacing the name Nemian, which appears infrequently in the mythology. Eventually, as time passed and the myths evolved to incorporate social changes, Danu splintered into numerous female goddesses, each with their own story, importance, and geneaology.

In feminist thealogy, this splitting into of one into many is part of the final step in the patriarchal takeover. Religion had to reflect the culture so before the goddess could be replaced by a male god as representative of a male-centered society, the goddess first had to be dismantled. The first step was to split her into her many forms, i.e. a goddess of fertility, of warfare, of poetry, of healing, etc. These various goddesses could then "marry" other gods (Eller 2001, 53). Gimbutas points out that these goddesses are consorts of the gods and while often beautiful, they become little more than the wife or daughter of an all powerful god with no real import or power of their own. The Morríoghan, and goddesses in general, would continue to suffer further demotions:

In historical times, Vulture and Owl Goddesses continued in the forms of Athena in Greece, and the Morrigan in Ireland who turns into a crow or raven. Under the influence of Indo-European culture, both of these were militarized, granting victory or defeat to armies at the time of battle (Gimbutas 240). 


\section{CHAPTER THREE \\ DEVALUATION IN AGRARIAN SOCIETY}

The discovery of agriculture and its implementation have played a large role in theories pertaining to the advent of patriarchy and the demotion and eventual loss of many goddess figures. It has been speculated that agriculture was the first step towards a patriarchal culture, which is ironic since the discovery of agriculture is usually credited to women. ${ }^{32}$ The section covering the development of agrarian communities examines theories from, among others, Engels, a socio-political writer and philosopher to whom many feminist thinkers and writers have turned to in order to better understand the conception of patriarchy and resulting hierarchies, regarding the effect agriculture had on women; from Dr. Gerda Lemer, a pioneer in the field of women's history; and Elizabeth Fisher who has written numerous books on gender, sexuality, and human rights in connection to women.

Also prominent in the treatment of agriculture in this chapter is Jared Diamond, who won a Pulitzer Prize for his book "Guns, Germs, and Steel" which explored the development of civilizations, sheds light on the development of warrior-ethos, wealth, greed, and population growth, the topics of subsequent sections within this chapter. All these authors support the thesis that women, and particularly the role of the goddess, have suffered under the development of "civilization". This chapter explains how the goddess

\footnotetext{
${ }^{32}$ It has generally been assumed that through women's food gathering they learned of cultivation. This assumes that women were the sole gatherers and the only ones likely to have come across this knowledge. Eller believes that many myths, such as a matriarchal pre-history and crediting women with the "superior" knowledge of agriculture, were created by men in an effort to reduce male anxiety concerning their dominant social position (Eller, 2001. 178).
} 
was demoted from a central figure to secondary role and how women in society were slowly, and unconsciously, being nudged into devalued positions.

Lerner attributes the decline of women's humanity to agriculture, primarily through the "theft" of women, which precipitated a trend she posits was originally instigated due to mortality rates of both women and children in childbirth. The frequent death of women in childbirth depleted the supply of women available to work the fields, perpetuate the species and care for young children. Therefore, she posits, tribes began to look outside their own for additional women, stealing them from neighboring tribes and clans when necessary.

The reason for such desperate measures as stealing in order to replace women and the seemingly "high value" placed on them was directly related to the necessary labor force required for crop maintenance (Lerner, 49). The loss of life in childbirth was devastating for men in economic terms, if not also on a more personal and emotional level. The economic viewpoint, says Lerner, reified both women and children, leading to a loss of basic humanity in regards to women and children who were seen primarily as property.

Elizabeth Fisher, author of "Woman's Creation: Sexual Evolution and the Shaping of Society", reiterates this idea, pointing to agriculture, irrigation, and increasing population as the primary elements that aided the development of patriarchy and led to the "economic and sexual subjugation of women" (247). Like Lerner, she identifies increases in population due to agriculture as the new source of women's value when she writes that "the encouragement of childbirth results from the need for more labor to work the fields intensively, to watch and feed the animals, and to produce a surplus for the few 
people at the top of the pyramid which now begins to take shape in organizing human societies" (247).

In the late $19^{\text {th }}$ century, Engels arrived at a similar conclusion. In the latest introduction to his book, The Origin of the Family, Private Property, and the State, Evelyn Reed writes that:

The rise of private property, on the foundations laid by agriculture, stockraising, metallurgy, and new social divisions of labor, generated these new social forces. As Engels points out, men of wealth required sons for the transmission of that wealth and the primary function of the legally wedded wife was to be the breeder of heirs to a man's property. Women became chattels in a consolidated family institution that served the needs of the men of the wealthy class (20).

In the text, Engels identifies large-scale agriculture as the catalyst for the development of private property, which produced wealth, patriliny, and monogamy as well as other aspects of the patriarchal social institution.

This assault on the humanity of mortal women was eventually paralleled in the cosmologies leading to an eclipse of goddesses as male gods took their place in the hierarchy of importance. Therefore, in the transition from oral traditions to historic civilizations there is a decline in the attention given to the goddess, who reflected the "old" ways. The focus was shifted to a male god as men took the role of property owners and rule makers and patriliny was firmly established.

It seems apparent to most archaeologists, anthropologists, and mythologists that women were connected with the earth through the concept of fertility from the earliest of times. Feminist theologians and current environmental crises have brought to the forefront the abuses, which many claim have been legitimized by Judeo-Christian 
scriptures, of the woman-earth connection. ${ }^{33}$ However, originally, the connection was more than likely a positive one that was gradually exploited in the transition to patriarchal religion and culture. It is necessary to explore the effects of an agrarian lifestyle and the demands it placed on society in order to develop a clearer picture of the devolution of the goddess. The Irish goddess serves as an interesting case study due to her strong grip on the Irish religious imagination, a grip that preserved her influence ${ }^{34}$ even through the transition to Christianity, a relatively female-hostile tradition.

Transitions to an Agrarian Lifestyle

No definitive explanation as to how agriculture was first discovered, or by which gender, can be determined. The reasons for the switch from hunting/gathering, a much healthier lifestyle at least in terms of a varied diet that provided a wide variety of nutrients and vitamins, to agriculture are also uncertain, but evidence for increasing sedentism throughout the Mesolithic ${ }^{35}$ led, inevitably, to theories of population growth. One of the more widely accepted theories, argued by Cohen, states that population growth was exceeding what foraging activities could sustain and as cultures became

\footnotetext{
${ }^{33}$ The connection of earth or nature with women allowed for the devaluation of nature and the plundering of natural resources without care or thought of the consequences on the basis of the already "other" status of women and anything related to her.
}

34 There are many examples of the continuing influence of the goddess in Christian Ireland. Two of the most obvious are in the conversion of lrish goddesses to Christian saints and in the traditional greeting that begins by invoking God, then Mary, and finally Brigid (an Irish goddess who is now a Christian saint).

${ }^{35}$ Sauer's (1969) research concluded that fishing communities were sedentary and attributed the beginning of agriculture to these groups. Harris's ( 1990) research also revealed sedentary lifestyles and related controls on female fertility to mobile groups. In his research, the population growth generally assumed to be the reason for adopting agriculture, stems from a sedentary lifestyle that no longer curbs women's fertility, thus leading to a population increase which demands more production than small scale horticulture can successfully yield (Thorpe 4). 
aware of this problem and the potential for crisis, they turned to large-scale agriculture (Thorpe, 4). Farming, then, provided people with rather reliable caloric benefits, and perhaps psychological ones as well. As it relieved a growing need, however, it also contributed to a decline in health, stature, and overall lifespan (Thorpe, 3).

Jared Diamond argues that agriculture has direct connections to the development of weapons, warfare, and to the spread of contagious infectious diseases. ${ }^{36}$ While growing populations may have been the impetus for the development of farming, the reverse causation my also be true. Once there were stockpiles of food and people were fully sedentary, the birth rate doubled and populations became much denser. Diamond points out that the stockpiling of food led to several inevitabilities: the need for someone to guard the food, the need for weapons to aid the person guarding the food, bureaucracy to handle distribution, and warfare to secure others' stockpiles when one's own were depleted.

Unlike hunter/gatherer societies, in an agrarian community there was a significant portion of the population that found themselves with 'free time'. Although farming required a large workforce and constant maintenance along with the guarding of any surplus food supplied, it did not require that everyone farm, since a typical harvest yielded surplus that could be sold to those without farms. With this free time, people could develop weapons, tools, art, and religious rituals, devote themselves to full time politics, as well as a host of other activities. Diamond argues that agriculture allowed for the development of chiefdoms or kingdoms, religious institutions, taxation, etc., while

\footnotetext{
${ }^{36}$ Diamond contends that humans with domesticated animals contracted mutant germs from them like smallpox, measles, and the flu, but eventually built up immunity to them. In wars of conquest they then had the advantage simply by introducing these germs into the community through their presence, thus severely weakening and killing much of the population.
} 
hunter/gatherer communities remained relatively egalitarian with unspecialized labor. This specialization, especially military specialization, backed by surplus food-stores led to the ability to engage in successful warfare, allowing agriculturists to easily overtake non-agrarian communities. Diamond points out that not only could societies with food surpluses maintain an army, as well as priests, and politicians, "these complex political units are much better able to mount a sustained war of conquest than is an egalitarian band of hunters" $(90)$.

Despite the drawbacks of intensive and continuous work for some families and their need for a large and capable workforce, the benefits of agriculture seemed to outweigh the difficulties and agriculture was adopted as a new way of life. Farming societies were established throughout Europe between approximately 7,000 B.C.E. and 4,000 B.C.E. Most of Europe had developed into agrarian communities by 5,000 B.C.E., farming newly introduced wheats and barley (Cunliffe, 136). Along with the cultivation of crops came the domestication and breeding of animals such as cattle, pigs, goats, and sheep as livestock. This transformed the way people related to both the earth and animals. Such vital relationship changes inevitably altered peoples' needs, values and beliefs in multiple areas such as economics, politics, communal relationships and religion.

Although the discovery of agriculture remains a mystery, its consequent surplus food supply is clear. It is this that began a host of problems that appear to further enslave earth and women in a patriarchal mythos, in that agriculture and domestication of animals conferred upon human communities the sense of control over the earth and animals. Despite the fact that people would have remained at the mercy of nature with regards to 
rich soil, plentiful water, untimely freezes, and other natural occurrences that could ruin a crop, they had developed a considerable degree of control over the earth, especially since many of these issues could be resolved through basic irrigation techniques and animal waste used as fertilizer. All this resulted in a profound lifestyle change and the transformation of social values in newly agrarian communities, a change which was reflected in the mythologies. Agriculture, at least in its fully developed phase, caused those who worked the land and lived off of it to develop a close relation with a much more restricted area of earth. In lreland, when the goddess became the earth tribal warfare arose at east partly as a way of protecting the goddess who had become incarnate in one's own land.

\section{Procreation}

Initial research concluded that early people had little, incorrect, or no knowledge whatsoever of the process resulting in the birth of a child. This information led to speculation that paternity and the devaluation of women began when men and women came to understand the role that males played in procreation. Afterwards, men naturally became interested, if not obsessed, with knowing who their offspring were. The impetus for a change from matrilineal to patrilineal descent seemed to have been born, at least im part, from this knowledge, which strengthened the desire to control women's sexuality.

However, later ethnographers admitted that some of this information appeared to be incorrect: in fact, most cultures did actually understand that man played an important role in procreation, even if they did not understand exactly how. Eller noted that many cultures understood that fathers and children were related but often did not consider the 
mother related to the child. The woman has been variously described as a "carrying sack" for a spirit child or a receptacle for the man's seed, but having no relation to the child (Eller 200195,96 ). Aristotle certainly took this idea to its penultimate by not even recognizing women as part of humanity and claiming female children to be "malformed" males, a result of man's carelessness in copulation or sign of his lack of virility (Sissa 75). This in turn may have contributed to high numbers of female infanticides as men did not want their weakness paraded about for everyone to see. Man's concern with paternity did not then develop with a sudden understanding of the connection between sex and childbirth, but from another source, that of wealth.

Private Property, Wealth, and Greed

Agriculture had a profound effect on civilization and with its adoption many other facets of society were transformed. The communal form of living and practice of both polygamy and polyandry were abandoned in favour of the "pairing" family, or marriage between one wife and one husband, though husbands were usually not bound so strongly as wives to sexual fidelity. Matrilineal lines of descent were overthrown and replaced by patrilineal inheritance rights. Women's sexuality was tightly controlled, slavery became profitable, and the newfound position of "wealth," in terms of crops and livestock, cultivated greed, created recognition of private property rights, and helped to make warfare common.

Wealth and greed aided in the development of warring cultures and were major contributing factors in the demise of women's position in society. However, they are only two factors in a complicated web of changes occurring in pre-history. With land to 
farm and protect, the idea of private property was emerging and the shift from matrilineal to patrilineal began. The idea of private property, previously unknown, re-structured the social values of the community. Status was determined by how much land and how much food one had. New ideals "of leadership, hospitality, and of negotiation with the implicit threat of force" became the new hierarchical structure that would dominate for the next 7,000 years (Cunliffe 210). Agriculture, the disintegration of communal living in favour of the biological family unit, and the ownership of private property are closely intertwined in the development of patriarchy and the devaluation of the goddess.

Private property most likely began with herds of livestock. Engels admits that there is no way to know whether the patriarch, Abraham, was considered the owner of his herds "in his own right...or by right of his position as actual hereditary head of a gens", in which case it is theoretically communal property (84). Originally, any wealth obtained through livestock or harvest would have belonged to the community. However, the presumed gender division of labour of early communities led to later problems in private property. Men were likely considered the ones responsible for animal foods in the hunter-gatherer situation and so in the agrarian community, ownership of livestock naturally became the property of the man. Likewise, household instruments used in gathering and preparing food were retained by women. This provided for a disproportionate share of wealth becoming the sole property of the man (Engels 67).

The wealth accumulated from farming and livestock undoubtedly began to make the man's position in the community more important. Although it was women and 
slaves $^{37}$ who farmed the land and tended the flocks, the wealth produced by this labour belonged to the man, as did the slaves. ${ }^{38}$ A man's status was measured in terms of his "wealth." While wealth created an abundance of food from both agriculture and livestock, this naturally had the capacity to provoke greed. Greed and envy demanded the acquisition of further "wealth" and represents another layer of female devaluation in the warring culture. While it is highly unlikely that this is the first instance of greed, it is possible that this is the first instance of large-scale collection of foods and arable land. Anthropologist Peggy Sanday points out that in warring cultures, women were severely marginalized, while in the earliest cultures, women and men seemed to exist in an egalitarian system. Sanday does not promote the goddess-worshipping culture of "feminist matriarchalists", but rather proposes that a communal system had been in place that valued both sexes.

Wealth and greed seem to be assumed in the theories of Engels, Fisher, and Lerner when they state that women were stolen, reified, and valued as a workforce in agrarian communities. Even Eller, who finds very little to agree with concerning theories of patriarchal devaluation, admits that the idea of greedy Indo-Europeans expanding into southern territories to rape and pillage simply because they could, is not an "outrageous hypothesis" (Eller, 2000, 165). She then addresses other plausible theories, however, for

\footnotetext{
${ }^{37}$ Slavery had previously been used primarily to maintain peace between neighboring tribes but had no great profit attached to it. Agriculture as a labour-intensive way of life made slavery profitable both in terms of output and as the property of man.

${ }^{38}$ Engels believes that in agrarian societies, men retained their association with providing food while women were responsible for its preparation. However, this does not account for women's gathering activities and only creates the question of why men's contribution in a hunting/gathering society was more prized. This may have to do with a relative scarcity or intermittent retrieval of meat, therefore placing greater esteem on food from the hunt.
} 
why Indo-Europeans expanded their territory. That they did expand is indisputable from a linguistic perspective; however, why they did remains in question.

\section{Monogamy}

A further layer in the web of patriarchy and devaluation of women, and thus the goddess and earth, is the development of monogamy. Monogamy seems to stem from previously mentioned theories of the reification of women. Levi-Strauss was one of the first to point out that the pairing marriage in a patrilocal culture was really a ritual between two men where property, or a material "thing" was exchanged. He correctly saw this as dehumanizing for the woman who was defined in material terms under these circumstances even when and if her feelings were taken into consideration and she was in agreement (Levi-Strauss 115). Ten years later, Fisher argued a similar point in the shift from matrilineal to patrilineal descent. She found that "patriliny is more effective for growth only where things are more important than people and where people are produced as things, tools to be used for the aggrandizement of others" (265).

The root of reification of people lies in the evolution of the mind. 150,000 years ago, early modern humans had developed technical and social intelligence but had not integrated these concepts. Steven Mithen argues that the "roots of denying people their humanity would appear to stretch back to the dawn of the Upper Palaeolithic" (196). He argues against the idea that these early people lived peacefully, but suggests that they didn't have the ability to see each other as "other":

The idea that our ancestors may have lived in an idyllic state of cooperation and harmony was shown to be nonsense as soon as Jane Goodall, in her 1990 book Through a Window about the chimpanzees of 
Gombe, described how she saw bloodthirsty brutal murder and cannibalism of one chimpanzee by another. There can be little doubt that Early Humans engaged in similar conflicts as they attempted to secure and maintain power within their groups, and access to resources. But what Early Humans may have lacked were beliefs that other individuals or groups had different types of mind from their own - the idea that other people are 'less than human' which lies at the heart of racism [and sexism] (196).

He argues that with the development of the Modern Human Mind, technical intelligence (thinking about objects to be manipulated) and social intelligence (thinking about people) merged (thinking about people as objects to be manipulated). This occurred at different times in different places, but most groups had developed this type of thinking between 60,000 and 30,000 years ago.

Monogamy represented a shift from a sexually carefree society where the mother's brother had more stake in the raising of children to one where knowledge of paternity was valued and women's sexuality was tightly controlled. This contributed greatly to the further reification of women. It also led to such theories of male seed or sperm being the true source of life and allowed men to continue a carefree sexual lifestyle while demanding exactly the opposite from women. In the New York Times, Adrienne Rich wrote: "male domination has been founded on male control of female sexuality and reproduction, on institutionalized male ownership of women and children".

\section{Elements of Transition and Devaluation}

It is clear that agriculture, private property, wealth, greed, and monogamy are all intertwined and represent some of the leading causes in the reification of women and the 
devaluation of the goddess. The questions, undoubtedly pondered by men of these societies, are; what kind of role does the goddess play in a patriarchal society? Is she even necessary? How can the female form be held up as a representation of divinity when the position of mortal women is so antithetical to that of the goddess? And if the goddess is deemed unnecessary, how is she dethroned or replaced?

Sudden alteration in the religious mythology of a culture is rarely welcomed. Instead, a gradual transformation usually takes place as new ideas, gods, and rituals are introduced. The first transformation was to take Danu (Anu), the Goddess of Eire, ${ }^{39}$ and splinter her into numerous goddesses. Eller describes this technique:

The Kurgans insinuated their propaganda into the psyches of matriarchal peoples by splitting the matriarchal great goddess into dozens of goddesses, each with her own "department." These goddesses were then married to Kurgan sky gods (or raped by them) to form a dual-gendered, male-dominated pantheon. (Eller, 2000, 53).

This seems to be the case in Ireland as well as other Indo-European mythologies. Little is heard of Danu, who rarely figures in the written texts, but instead goddesses such as the Mor-rioghan, Brigid, Aine, Medb, and many others abound, each with their own "department". The Mor-rioghan, a war goddess, is said to have become the wife of the Dagda, the main god of the Celts, while Aine, whose story is related in one $8^{\text {th }}$ century text, is raped by Ailill who then takes her as his wife. Entire genealogies were created for

\footnotetext{
${ }^{39}$ Eire is one of three goddesses, Eire, Banba, and Fodla, all of which are a name for the country. Eire comes from the older Eriu which was the Celtic word for land. These three goddesses reflect the sacredness of the land. The story of the meeting of Amerigen (first Celt said to land in Ireland) with Eriu at Uishneach, the heart and physical center of Ireland, portrays what happens when nature is not treated with reverence. Eriu is not interested in their worshipping her; instead she welcomes them and their gods, and asks only that the land bear her name and that she (the land) be treated with respect. Donn, eldest of the sons of Mil, ignorantly treats Eriu with contempt instead of gratitude and is quickly drowned by the forces of nature for his carelessness.
} 
the goddesses that often conflict with one another, belying their rather random invention, and in the end, there is little assurance regarding supposed parents of these goddesses.

The goddess loses her power and significance once she becomes the consort of a more powerful male god. The next step is to link her with certain undesirable traits and horrific images such as murder, warfare, suffering, death, etc. This transformation is much more subtle as the goddess continues to exemplify the sacrality of the land until she is militarized. The Mor-rioghan is a perfect example of this system of devaluation as she is the goddess of sovereignty. Before examining her role in sovereignty and warfare, it is necessary to look at the Irish understanding of the land and their relation to it.

The importance of the Irish landscape

Dr. Ron Hicks of Ball State University has done extensive research in the area of landscape archaeology in Ireland and the importance given to "place" in Irish myth. His work in trying to better understand the connections between the religion and the land has led him to conclude that the mythology clearly illustrates the sacrality of the landscape. The numinous quality of the land was understood by both the Neolithic and Celtic Irish and it is possible that this concept may extend as far back as the Paleolithic.

The mythology seems to show a landscape that was considered sacred from the earliest of times. Ireland is still referred to today as the "sacred isle." This sacrality was attributed to the landscape by the pre-Celtic religion as well as the later pre-Christian and Christian culture. Like the Greeks, the Celts and their Druids often practiced in sacred groves, or nemetoi, and forests. Trees of all sorts were considered sacred and evidence suggests that trees were either worshipped or an important part of rituals. Many monastic 
settlements, which were built on sites known to be sacred and powerful to the pagans, reflect the importance trees played in the religious practices: Cil Dara, better known as Brigid's Cathedral in Kildare, is translated "Church of the Oak," and Columba's Durow means "Oak plain". These are but a few examples of the numerous references to trees in sacred sites today. It is also substantial proof of Christians building over pagan sacred sites in an effort to convert the people. Many other elements are connected to trees such as the Celtic "tree of life" and the Ogham ${ }^{40}$ alphabet, by which each letter can be represented by a corresponding tree. Pennick sees "the ensouled nature of trees" as a perfect vehicle of inspiration both to the Neolithic community in Ireland as well as the Celts (31).

Unfortunately, with the advent of an agrarian lifestyle trees were felled at alarming rates in order to clear land for crops of wheat and barley as well as for livestock such as cattle, pigs, sheep, and goats (McCaffrey, 35). By the early Bronze Age, deforestation had caused the bogs to spread ${ }^{4 !}$ and cover earlier fields, which in turn caused the climate to become wetter. Between the $9^{\text {th }}$ and $12^{\text {th }}$ centuries C.E. the felling continued and warring clans often set forests on fire to drive out their enemies. Even blacksmiths, who used wood for their fires and shipbuilding, took their toll on the forests as well (Pennick, 26). Ireland was essentially deforested by the $17^{\text {th }}$ century, leading to laws that encouraged the planting of trees. Remnants of the great sacred forests and

\footnotetext{
${ }^{40}$ Ogham is the earliest known alphabet and form of writing in Ireland. It consists of various lines along a vertical axis and can be found carved into rocks.

${ }^{41}$ At the beginning of the $20^{\text {th }}$ century, bogs accounted for $14 \%$ of the Irish landscape.
} 
groves are all but gone today, except in Killarney National Forest where one sees a remnant of the old growth forests.

But trees were not the only sacred aspects of nature. There is the stone of kingship or "stone of destiny" at Tara ${ }^{42}$ that is said to cry out under the legitimate king. Huge boulders found near the ocean's edge were said to be auspicious and to "embody elemental powers" (Dames, 18). Springs and wells were generally deemed sacred and many a mountain or hilltop was considered holy both in pre-Christian and Christian times.

It is significant to note that the sacrality of the land remained even with the new religion of St. Patrick, especially considering the many Christian theologians such as Aquinas and Augustine who were suspicious of both women and nature as evil and unredeemed. However, the Irish had a long history and relationship with the land and nature to them was inherently good, even sacred, and God was present in the land itself. In contemporary Ireland, myths of gods, goddesses and Otherworld ${ }^{43}$ beings and the plains, hills, mountains and rivers they inhabited continue to live on through festivals and pilgrimages ${ }^{44}$.

\footnotetext{
${ }^{42}$ Tara is the royal seat of kingship for the Connachta, lying just north of Dublin. Further to the north is Emain Macha, royal seat of the Ulster sect. Both are protected as historical sites, though Tara is under threat of the same destruction Stonehenge has suffered with a freeway planned to run within yards of the royal seat.
}

${ }^{43}$ The Otherworld, or Tir na n'Og, is generally understood as a beautiful land where one goes after mortal death to live out a lifetime before returning to the material realm once again. This is in keeping with the pre-Christian ideas of transmigration. It is often placed off the west coast, but portals may be found to the Otherworld through sidhes (megalithic structures) and other mystical sites.

44 The most famous pilgrimage in Ireland today is Croagh Patrick, a mountain standing 595 meters on the west coast in northern Connemara. The most devout pilgrims conquer the rocky terrain barefoot, crawling the final steep ascent to the top. Almost all of the early Christian figures of importance are related to specific sites, such as glens, valleys, or mountains as nature and religion were inextricably bound together in the Irish imagination. 


\section{The Goddess in Transition}

As mentioned above, it is clear that the names of the Danube as well as the Don rivers were originally derived from the Mor-rioghan. As the shift to a farming lifestyle was implemented and basic societal values evolved, so did the position of the goddess. Once communities became settled, the land acquired significant new meaning in the out of human hope for fertile soil and plentiful crops. The "old" sources of life, previously seen in the river, lake, or sea, were supplanted by the quest for bounty in the harvest, and so goddesses with detailed mythologies related to the earth quickly developed, such as in the case of the Mor-rioghan, who became a symbol of sovereignty.

It is believed that in agrarian societies, particularly Indo-European ones, that the goddess represented the creative life force and normal cycles of birth, life, and death. She was equated with the earth as a procreative force providing sustenance. She eventually took on further natural associations, representing the waxing and waning of the moon, and occasionally the movement of the sun, though this position was generally reserved for male gods. It has been speculated that early cosmologies exemplified a psychology that honored and respected both balance and the creative aspects of nature.

The very nature of religion is a process of gradual and constant development that, once inert, fails to keep pace with the spiritual imagination of its people who are in a constant state of evolution. The Mor-rioghan experienced a transformation and found a place among the new ideology of an agrarian society. The female form, responsible for creation of life and nurture of the vulnerable, was easily equated with the earth. She was also a creative force in her production of food, and by providing this sustenance also

performed a nurturing role. While the association between earth and women may have 
originated much earlier, the multitude of "earth" goddesses who appeared and were credited with the discovery or gift of agriculture was a cross-cultural phenomenon. The earth's representation as feminine was without question an idée fixe within early agricultural societies and signified the shift in emphasis from water to earth goddesses.

This marked the first major demotion of the goddess who subsequently became the genius loci or spirit of the place and, therefore, a static force capable of being controlled by man, just as the land can be portioned off and harvested by man with a rather certain degree of control. However, the creative forces of both women and earth could be harnessed, but not dismissed in the androcentric mind, which reserved for the goddess prominent, yet surreptitiously subordinate, positions in the cosmology. The focus of the goddess moved away from water and she instead became a representation of the earth in early mythologies, leaving few notable water goddesses. ${ }^{45}$

In contrast, David Leeming eminent mythologist, argues the opposite, that femaleness, human and divine, would have gained in status with the agricultural revolution:

Clearly the most important metaphor for fertility itself was sexuality in connection with the birth-giving female, and as agriculture partially displaced hunting as a primary food source, the woman would have gained in stature (32).

According to Leeming, agriculture would have created an environment where the female would be viewed as a representation of fertility. This fertility applied to nature or earth, and ultimately to all living things, including humans. Woman was then a representation

\footnotetext{
${ }^{45}$ The goddess Boand is specifically related to the river Boyne above which the great megalithic monuments of Newgrange and Dowth are situated. However, she is also said to be identical to Ethne who is related to grain and thus a sovereignty goddess. This most likely reflects the desire to transform water goddesses into those of earth goddesses.
} 
of divine fertility in the agrarian community and the goddess was the supreme deity. However, Fisher reveals the inherent problem in this psychology when she writes:

When woman is worshipped for her "natural" powers, woe betide her humanity. Forced breeding and sexual repression go together. Limitations in the area of male-female sexuality led to the overdevelopment of maternal sexuality, and this in turn led to the subjugation of women as it is practiced in the historical Western patriarchy (252).

Leeming agrees with other scholars that with the shift to farming societies, came "technological improvements in weaponry and tools. .." (5), which leads the argument back to the consequences of warfare, the development of the sovereignty goddess and her militarization. Ultimately, a social ethos based on warfare does not contribute to the welfare of either women or men, but is particularly damaging for the status and welfare of women. Carol Christ believes that "the institutionalizing of warfare as a way of life is the single most important factor leading to the subordination of women" (Rebirth 61). 


\section{CHAPTER FOUR}

\section{SOVERIEGNTY AND WARFARE}

The earth and the seasons that governed the growing cycle in Ireland were of ultimate concern to the Irish. The impact of agriculture and the emphasis placed on it is apparent in the mythology. The only way to truly understand the old Irish religion is to place it in the correct context: their overwhelming concern with the annual agricultural cycle, the crops, and the animals. The calendar and solar/lunar movements also need to be considered on a more abstract level (Hicks). Therefore, it can be expected that numerous goddesses related to the earth, crops and animals would emerge. ${ }^{46}$ This chapter explores this close association with nature and the emergence in the mythology of the sovereignty goddess. This role, in its connection to warfare, will be shown to be the next step in the demotion of the goddess.

The Mor-rioghan of Celtic society is clearly related to the land; names of hilltops and ancient cooking sites in Ireland reflect her association with the earth. In county Meath, near Newgrange, there are two hilltops identified as her breasts, ${ }^{47}$ a common Irish form of honoring their goddesses. O'hOgain states that the Mor-rioghan "is an emanation from the earth-goddess, her battle-context reflecting contests for land in the material world" (O hOgain, 307).

\footnotetext{
${ }^{46}$ The main way in which Irish goddesses are related to animals is through their powers as shape shifters. As seen above, the image or spirit of the Mor-rioghan is often represented by a crow called the badb or hooded crow, but she has also been known to change into a wolf, a heifer, and an eel.

${ }^{47}$ The two hillocks of the Mor-rioghan are known by the name 'dá chích na Mórigna.
} 
The Mor-rioghan's relation to the land is best seen in her aspect as Macha. As Macha she was the land-goddess and represented sovereignty. Her home was the royal seat of Ulster, Emain Macha, in Armagh. While the earliest roots of Macha tell of a land goddess, she is also an aspect of the war-goddess. Here the mythology of the patriarchal Celts influenced the transformation of the goddess by giving her mixed roles that sometimes appear antithetical to one another. For instance, in one tale she represents a plain and its agricultural activities while another mediaeval gloss describes her "fruitcrop as the heads of men that have been slain" (O hOgain, 308). As we will see later, these two roles are not opposed in the patriarchal mythos of the Celts, but interdependent.

Mary Low reports Macha as having been worshipped in the Armagh area and identified as land goddess, mother goddess, war goddess, and as a solar deity (Low, 29). Low sees Macha, like so many other early Celtic deities, as a goddess who is difficult to categorize. The difficulty in categorizing early Irish deities, especially goddesses, arises from their transformative position in the mythology. In order to fulfill androcentric desires "old" goddesses had to change to reflect male interests such as warfare and general destruction in addition to their earlier creative and fertility related roles.

While the earth-goddess has been much celebrated in pagan circles, she is most likely a patriarchal invention. Ruether has pointed out that linking women with "earth, matter, and nature, while identifying males with sky, intellect, and transcendent spirit" has provided the necessary link in creating a cosmological model of domination (Ruether, 3). This model furthers the position of the male ruling class while creating slaves of women and nature. 
Macha's identification with a solar deity is especially perplexing. Although not unheard of, female solar deities are somewhat rare. The best known are Amateratsu from Japan and the Egyptian goddesses Bastet and Sekhmet. ${ }^{48}$ In general, Indo-European myth posits a male sky god as the source of earth's (woman's) creation, making the woman dependent on the man through whom sovereignty flows. However, in Irish myth, this solar deity is either lacking (where identified, ${ }^{49}$ it is usually by a Roman source attempting to equate Irish deities with Roman ones), or is a goddess. In Celtic mythology, the land was the ultimate source of power through which sovereignty was bestowed and through which the entire cosmology functioned; the sun god or goddess performs a lesser role.

\section{Sovereignty}

The ritual marriage of the king to the land continued, at least in metaphor, until the seventeenth century in Ireland (Larrington, 129). The term banais righi, meaning "wedding feast of kingship" implied the ritual marriage of the king with the goddess of his land. The king needed the grace or blessing of the Sovereignty goddess or his reign was not legitimate. Through this ritual marriage the earth was renewed, the land was

\footnotetext{
${ }^{48}$ It should be noted that Sekhmet represents the destructive forces of the sun and shares a considerable number of qualities with a typical war goddess. In Irish mythology, $O$ 'Rahilly believed Etain, having no real connection to the earth or sovereignty, to be a sun goddess; however, Dr. Ronald Hicks argues that she is a moon goddess, and more specifically the winter moon as her movements in Tochmarc Etaine match the moon's cycles, as does the comment that at dusk Oengus draped a purple cloak around her so she regained her color.

${ }^{49}$ Dr. Ronald Hicks feels that many deities' attributes may shift with the seasons, relating back to the importance of the agricultural seasons. For instance, during the height of summer, a god may be equated with the sun, but as the seasons shift, that god (Lugh) is encountered killing his maternal grandfather who possesses a magical eye in the center of his head (possibly a sun figure), therefore ending the summer season, at which time Lugh then comes to represent the harvest (Hicks).
} 
fertile, and the people were granted peace and prosperity. The king, then, was a consort of the goddess who was the ultimate source responsible for the protection of the tribe or clan. The goddess was obviously a goddess of the earth, capable of bestowing plentiful rains, abundant harvests, good health and fertility to the people. As Clark points out in her explanation of sovereignty, the "state of the country is naturally the best proof of his fitness to be king" (Clark, 111). If the king were not on good terms with Otherworld beings, especially the goddess, his reign was likely to be beset with famine, disease, and eventual conquest by neighboring enemies. Brenneman remarks on the importance of agriculture to the Celts:

What I wish to emphasize. . is the overriding importance of agriculture to the Celts. . The religious constellation that developed from this amalgam centered upon the sacrality of the earth ... For example, one of the central rituals of pre-Christian Ireland was the inauguration of a chief. . This rite involved the mating of the prospective chieftain with the land, which was understood to be a goddess. The survival of the people was dependent on the sovereignty of the chief, which was bestowed by the goddess, the land. Thus, it becomes clear that survival was dependent upon the success of agriculture, not upon cattle raiding and hunting.

Macha and Queen Medb are the best-known goddesses of sovereignty and both are aspects of the Mor-rioghan. Macha's association to the land is clear. Her role as a sovereignty goddess, as we have seen, in the tale of her race against the horses, has several possible interpretations. One is that it recounts an ancient fertility rite. It could be a sovereignty tale or the misogynistic theory that women, especially Otherworld women, drain a man's strength and virility. It could stem from male jealousy of women's creative properties, which provokes imitation of women's labour pains, or as Eller would espouse, it could be the practice of imitative bloodletting through warfare. Of the many possible interpretations derived from the race story, which will be explored, two things 
are most clear; Macha has equine associations (a symbol of male power) and she is without question more powerful than the king's horses. Not only is Emain Macha, ${ }^{50}$ the royal seat of the Ulstermen, named after her, but also the city Ard Macha, known as Armagh. Her curse on the Ulster men serves to legitimate the sovereignty of the Connachta, who took Fort Navan (Emain Macha) in the $4^{\text {th }}$ or $5^{\text {th }}$ century.

The story of the race may also be understood as an Irish form of Hindu pati-vrata, or sacrifice of the self to one's lord and master. When Macha hears that her husband will be killed unless she races, she willingly sacrifices her own life to save her husband's by appearing before the king, hours before giving birth, to indulge his courtiers' phallocentric bet that she can outrun the king's horses.

The sovereignty myth is interesting because it is an amalgam of patriarchal ethos and ultimate female power, which, if it serves no other function, at least seriously confuses scholars of myth. The myth is clearly part of a warrior culture whose main symbols were represented by the power of animals, namely horse and cattle, and whose emphasis was on warfare (Brenneman, 75). Paradoxically, these are not the ultimate source of power; instead, the warrior, king and patriarchal society remained dependent on the earth goddess. It was her blessing that made possible their existence. Brenneman views Irish Celtic culture as "empowered by the feminine" (76) and writes:

...it is clear, however, from a terse survey of Irish myth that male leadership was dependent on the power of wisdom and regeneration known as sovereignty and was possessed by various feminie deities or demadeities (75).

\footnotetext{
${ }^{50}$ Emain Macha is translated "Macha's Twins," after the two children she bore upon her death, after beating the king's horses in the race.
} 
In the absence of a true sky god, ${ }^{51}$ it appears that the goddess is the sovereign power, though her power is used to justify the "patriarchal structure of the warrior aristocracy" (Brenneman, 76). In this culture, it seems as though the goddess was the empowering source that made patriarchy possible. Gross points out that "once large scale warfare and significant social hierarchies become part of human society, women and goddesses readily support and patronize both" (Gross, 83).

While the earth is an important aspect of divinity and is imaged as a goddess as the root of real power, it is also a secondary position as Brenneman notes; "Feminine power, for the most part, lay in the background, or more precisely, underground in what was called the Otherworld (75)". He continues, remarking on the dependency of male power on the sovereign power of the goddess for validity, but this does not change the fact that the goddess's position now "lay in the background." The earth, water, and air also lie in the background of mortal existence and have been badly neglected and abused precisely because these elements are not in the forefront of divine meditation and prayer. By being relegated to the "background", the goddess was easier to dismiss or attach negative connotations to.

The goddess's position of importance was also threatened from her association with the land itself. The real challenge was in maintaining sacrality of the land. Once her earth characteristics were the primary focus, and she was recognized primarily as a land goddess, she became static and her centrality would once again be transformed. Eventually, by the $16^{\text {th }}$ century, the goddess became so trivialized that she could be

\footnotetext{
${ }^{51}$ The Romans equated the Celtic deities with their own better-known gods and believed Lugh to be a "sun god" within the Celtic pantheon. However, Lughnassadh, the festival created by Lugh to honor his foster mother is clearly a harvest festival and has no relation to the functions of a sun deity, but rather to the earth.
} 
eliminated from any important aspect of the cosmology altogether. Becoming a static earth goddess proved, then, to be a step towards her eventual demise.

It can further be argued that the sovereignty goddess is ultimately a covertly subordinate position created to appease women. Macha's reticence, but eventual obedience, in racing the king's horses depicts the ability of males to dismantle even a goddess, who must bow to the king's wishes, no matter how absurd. However, the men do not escape their folly without being cursed. Her curse, that they be weak in crisis, is then attributed to women, an idea that would later become all too familiar in JudeoChristian mythology where woman is responsible not only for the fall of a man or a clan, but for all of humankind. The idea of an "earth" goddess, then, is the first step in the devaluation of the goddess, which is quickly followed by devaluation of everything associated with her.

\section{Warfare}

In Irish mythology it is impossible to separate the functions of the goddesses of earth, life, and fertility from those of the goddesses of war who preside over battle and assign death to their enemies. Green explores this issue in her book, Celtic Goddesses:

...these apparently polarized concerns were both under the tutelage of the Irish sovereignty-goddesses. In fact war and land need not be opposed images: at a basic level, war may be necessary to protect territory, so battle and guardianship are linked. The earth can only be successfully cultivated within the context of peace, because it requires constant attention, and thus the protection of boundaries is essential for prosperity (72).

She also remarks on how "blood and carnage" on the battlefield served as a way to "replenish" the earth. This cyclic understanding of death being the creative power 
leading to rebirth can be understood as theomachy ${ }^{52}$ and is undoubtedly an androcentric version of the power of creation. If man lacks the necessary human organs to birth young, he can still participate in the creative process through death and destruction. In this androcentric interpretation, the militarized goddess has been transformed from a vital force sustaining a cycle of birth and death, to a power responsible for the destruction of human mortal life. In a culture whose most basic and revered skills are those of warfare, one of the only positions available to the goddess is to become part of the warrior ethos of destruction. After all, there is little need for the creative powers of female fertility in a civilization of warriors. Condren points out that motherhood is actually a handicap in such a society because it prevents female members from participating in the social norm of warfare (42). Therefore, the goddess of death became a more active figure while goddesses of fertility, sustenance, earth, and water fell into disuse. From this point on, the only truly functional goddess was one of sovereignty and war.

Condren believes that until the goddess could be symbolically killed, dualistic patriarchal culture could not fully come into being (Condren 24). By demoting and transforming the goddess, the natural cycle of life and death was broken, and thus matriarchy and goddess-centered religion was destroyed. The new hero ethos and quest for immortality had no place for the goddess of balance and nurture. The new patriarchy would eventually require a transcendent male deity rather than the immanence inherent in nature and matricentered religion. The only role left for the sufficiently demoted and subdued goddess was that of the goddess of war, violence, and death.

\footnotetext{
52 Theomachy, as defined by Catherine Keller, is "creation by battle" and is a common cosmology found in pagan mythologies (Keller 26).
} 
Condren believes that the story of Macha in Irish mythology preserves the actual event of matricide and the destructive shift to patriarchy. After Macha's mortal death at the end of the race, little is heard of her, other than tributes to her in place names.

The disappearance of Macha symbolized the elimination of the possibility of any woman-centered social system, philosophy, or religion. The Male Word, rather than the Female Womb, would take responsibility for ensuring the continuation of the social order, albeit that this Word was reinforced and sustained by a discourse on, and the threat of, death rather than life (48).

The issue that must be raised with Condren's interpretation of Macha is the development of a timeline. It is impossible to say when the myth first appeared, therefore, making it impossible to tell what comes "after." However, this does not negate the possibility of the myth preserving a tale of matricide.

Medb is another aspect of the Mor-rioghan and also a goddess of sovereignty. She is the only goddess described as personally engaging in warfare on the battlefield. O'hOgain believes that the common reference to her as "half red" is in relation to the contests for kingship at Tara which were invariably a bloody affair (293). Elizabeth Gray points out that in Irish myth, "the world of the gods is almost a mirror image of human society, with every major social role represented" and the story of Queen Medb, from the Ulster Cycle, seems to portray a society of equal, or at least possibly equal, status for men and women ${ }^{53}$ (185). Medb is seen as equal to her husband and other men in warfare, personal financial holdings, and in sexual freedom, if not actually superior.

\footnotetext{
${ }^{53}$ Queen Medb is a mythical queen whose name originally meant "one who intoxicates". She always kept more than one man at a time and had many husbands throughout her lifetime. The Táin Bo Cualingne tells the story of her battle for equal financial wealth with her husband through the acquisition of Cooley's bull. Cooley is eventually killed in the battle when Medb leads an army of children learned in magical arts into battle.
} 
As Medb she embodies all the elements of a sovereignty goddess; fortune, fertility, prosperity, sexuality, physical force, and death (Green 1995, 70). Medb appears to have enjoyed a life of sexual freedom by insisting that any man pursuing the kingship had first to submit to her sexual desires and become her husband. In this way, she declared, she could determine the best ruler of the land. In the tale Táin Bó Cuailnge, she displays both the element of seductress but also the element of ruthless warrior. In this tale she leads armies of hundreds, accommodating patriarchal pattems by becoming militarized. Most scholars recognize Medb as a "humanized" version of the goddess in this tale;

She is presented not as a goddess but as a warrior-ruler of the province of Connacht, and has clearly undergone a humanization-process whereby the goddess became a queen. As Marie Herbert puts it, Medb is the 'realisation in human terms of the goddess of sovereignty (Green 1995, 79).

Through her battles with Cúchulainn, she becomes vilified as she proves to be ruthless, stopping at nothing to kill him, including training children in magic and sending them into battle after Cúchulainn. Green argues that Christian redactors have regarded her so negatively, as thoroughly evil, precisely because of her human nature. They saw her as "an unnatural human woman, unacceptably promiscuous and a destroyer, rather than as a spirit. .."(79).

In essence, the benign earth goddess, perhaps originally evoking positive images, is transformed in the sovereignty myth to a humanized war goddess. War itself has generally always been attributed to the male psychology. Explanations for this type of destructive behaviour range on the one hand from the hormonal to the physiological, which propose maleness as naturally predisposed to violence and woman to be a naturally 
creative force, to, on the other hand, understanding warfare as a necessary evil associated with the invention of private property (also a patriarchal invention) and population increases. Eller takes a psychological approach to the problem of warfare, criticizing it not only as a patriarchal invention, but also as a "male menstrual ritual" (Eller "Living in the Lap" 168). She postulates that men engage in menstrual rituals of blood-letting out of envy of women's creative power, represented by their menses.

Similarly, Charlene Spretnak views war as the only "honurable" form of bloodshed that imitates women's menstruation. The war goddess creates a problem for neo-pagans and feminists today in their attempt to re-value women. In search of strong female archetypes to emulate, they have often seen the war goddesses, such as the Morrioghan and Queen Medb, as strong, positive reminders of woman's abilities. However, scholars have long recognized the underlying trajectory of the war goddess that reveals her waning value within a patriarchal culture that relies less and less on egalitarian politics, peaceful solutions, and respect for anything considered to be the Other. ${ }^{54}$ The high status of a war goddess, a deity who both demands worship and strikes fear in the hearts of humans, cannot endure. W.M. Hennessy, writing in 1870 , noticed that during his time, the name of Mor-rioghan's sister, ${ }^{55}$ or her trinitarian aspect of Badb, evoked "feelings of mingled dislike...[from the people] who remember the many tales of

\footnotetext{
${ }^{54}$ The term "other" refers to anything or any person that is not a heterosexual white male. Ascribing "other" qualities to any segment of the population inevitably results in the oppression of these groups. This includes nature, animals, women, slaves, minorities, and anyone of an "alternate" sexuality.

${ }^{55}$ The various trinitarian aspects of a goddess are most commonly referred to as "sisters" in Celtic mythology.
} 
depredation and slaughter in which the cunning bird ${ }^{56}$ is represented as exercising a sinister influence" (34).

It seems only natural, then, that the incoming Christian theology promising love, acceptance, and salvation for all would ultimately seem more appealing than a war goddess, despite Christianity's inherent shortcomings and remarkably pronounced androcentric nature. For when Christianity arrived, the Great Goddess had already been buried deep in the background through the sovereignty mythos, and the warfare association had made her a symbol of ruthlessness, murder, and fear. With such negative connotations attached to the goddess, a male-only religion may have seemed a welcome change. The eagerness to adopt the Virgin Mary in Ireland, which has resulted in numerous shrines dedicated to either her or Brigid, may stem from the older conception of the once peaceful and life- sustaining goddess.

${ }^{56}$ This is a reference to her shape-shifting abilities and common form of the crow. 


\section{CHAPTER FIVE}

\section{CONCLUSION}

We encounter the Mor-rioghan today in what may possibly be her final transformation as the bean si or, banshee. This chapter explains the current conditions of the devalued Mor-ríoghan as she was split into a bean si on one hand and Brigid, who would become a Christian saint and midwife to Mary. Just as Mary is a meek version of the goddess, the bean si is equally powerless and holds a role of little significance. These metamorphoses represent the final demotion of the goddess figure.

The bean si has her roots in the old mythology as the goddess Badb who is found, in the form of a beautiful young woman by a river, washing the spoils of Cúchulainn as he goes off to battle. To come across a woman at a ford washing was a sign of the unfortunate viewers' impending death. Patricia Lysaught, who has chronicled sightings and hearings of the bean si throughout Ireland, identifies two types of texts that deal with the death messenger; the si-woman-texts and badhbh-texts. The si-woman texts identify female figures connected to deaths in their ability to prognosticate, while the badhbh texts deal with figures that foretell death through the image of a beautiful woman washing the soon-to-be deceased's belongings at river's edge. She goes on to show that it was the si-woman texts that became predominant, even in the areas where the legend of the Badb was most prominent (Lysaught 192).

The Mor-rioghan is not alone in this transformation from sovereignty goddess to bean si. Several of the goddesses have been known to take on this role. The goddess 
Aoibheall came to the High King Brian Boru ${ }^{57}$ and warned him that he would be killed in the battle at Clontarf on the following day. She then decided which of Brian's sons should gain sovereignty of Ireland. It is clear that Aoibheall had a stake in the future of Ireland and is therefore a goddess of sovereignty. Patricia Lysaught mentions, "it is through the concept of sovereignty that some of the fundamental questions relating to the death-messenger belief may best be understood" (195).

In the $17^{\text {th }}$ century the well-known goddess Aine of Cnoc Aine (Knockainey) in the south came to the Fitzgerald family (also of the southern region) as a foreteller of death. In south Munster, the goddess Cliona is found performing the same role. The main behaviour these goddesses employ is weeping and lamenting, which may have some influence on the tradition of keening ${ }^{58}$ as well. Texts and stories of this sort have been dated to the $8^{\text {th }}$ century. They clearly embody elements of earlier Celtic mythology while managing to merge aspects of Christianity into them.

Today, the bean si is most often connected to a particular family and warns of an imminent family death through her wailing. She does not appear to all members of a family and she does not speak, as the earlier manifestations did. In Ireland today, one who hears the bean si knows only that someone is about to die, or has just passed away, but they are not granted the information of to who this tragedy might befall.

\footnotetext{
${ }^{57}$ Brian Boru is a historical figure and was the High King of Ireland from 1002 until 1014 C.E. On Good Friday, in 1014 at the battle of Clontarf, Boru desimated the Viking forces, but as they retreated one of the Viking leaders, Bothair, murdered the High King. Malachy, who had been sharing the Kingship with Boru as the ruler in the North of Ireland, resumed his position as High King and though Viking presence continued in Ireland, their military power was destroyed. Boru remains a highly celebrated figure in Irish history today.
}

${ }^{58}$ A keener is a woman who is hired by the family of a deceased to wail and moan over the loss of their loved one. 
In almost all incidents where she manifests visually, the bean si is said to be wearing white. Interestingly, Gimbutas recovered many "stiff nudes" buried alongside the dead in graves, which she believed to be symbolic of the White Goddess of Death. These were found in every culture throughout Europe and date from the Upper Paleolithic through the Bronze Age. Gimbutas believed death was envisioned as a "white bonelike form" and found that "without exception she is carved of bone, marble, or alabaster, and if these materials were not available, her images were molded from lightcolored clay or sculpted from light-colored stone" (Gimbutas 1991, 240). She also found the White Goddess of Death to be expressed in the form of birds of prey, the Morrioghan's most familiar shape-shifting form. Gimbutas points out, "in Ireland, the foretellers of death are always birds that make horrifying wailing sounds" (Gimbutas 1991, 242).

In this way, the Mor-rioghan lives on, one attribute of sovereignty still intact, but she is now responsible for the most unwelcome of news. She no longer has her lifegiving, life-sustaining, protector qualities. All she can do is foretell death, but she seems powerless to stop it and does not perform the same announcement service for births. It is hard to imagine further demotion unless full demonization will be realized in a transformation, which is not impossible considering that unbaptized children are often thought to become bean si. As long as the Mor-rioghan maintains her separate status from the mythos of Christianity as truly pagan, she may well come to share the fate of Lilith, the first wife of Adam in the Jewish Talmud, who was demonized and is still feared today across parts of Europe. 


\section{Brigid as Pagan Goddess and Christian Saint}

Within Christianity, Brigid remains a strong focus in Ireland. Some of the later mythologies that include her place her at the birth of Christ as the mid-wife. The sacred pagan land at Cil Dara (Kildare) was taken over by Christians who built a church and convent on the grounds. The cult had been led by a Leinster saint (452-524 C.E.) who took Brigid as her name and came to be second only to St. Patrick as patron saint of Ireland. She was called "Mary of the Gaels" and she and the nuns kept an eternal flame burning on the grounds, which was said to have been started by female Druids who congregated there. ${ }^{59}$ The flame was extinguished around the time of the Reformation but has been recently relit by the Sisters of Saint Brigid in Kildare who lead pilgrimages to her well outside of town (Joyce 43). As mentioned earlier, Brigid is often considered related to the Mor-rioghan, not directly as her Trinitarian aspects are, but in their roots as splintered goddesses of the same Great Mother Goddess Danu. The Mor-rioghan's "department" was sovereignty and warfare while Brigid's was fertility, light, fire, poetry, healing, and animals, the typical features of a spring goddess.

The Mor-rioghan's "devolution" can be seen clearly in mainstream theories regarding demotion, devaluation, militarization, and vilification of the goddess. Much of Gimbutas's research elsewhere in Europe seems to support others' interpretations regarding the meanings of the early Irish myths. Even without subscribing to theories of devaluation, it would be clear that the goddess lost her hold on the religious imagination, persevering only in the most trivialized of forms. However, if current theories of the demotion of the goddess can easily be traced in the Mor-rioghan as well as in other Irish

\footnotetext{
${ }^{59}$ It is worth noting that Saint Brigid was said to have been raised for many years by a Druid.
} 
goddesses and as a product of the Indo-European religious imagination, it is more than likely that other goddesses of I-E mythologies had also fallen victim to the same pattern. The Irish religious imagination seems to have merged the mythos of their Celtic ancestors with that of Christianity and in doing so, retained elements of the goddess, in one form or another, more so than in other "Christian" countries.

Many of the "matriarchalists" do not see this in-between stage (between a former matristic culture and Christianity) of Indo-European mythology as wholly patriarchal. Eller notes that many feminists do not believe culture became truly patriarchal until the Roman Empire and Christianity forbade the worship of goddesses, who were replaced by "a single male-god called Father" (Eller 2001, 53). Some scholars have found evidence of the birth of patriarchy in the Indo-European myths, which then opened themselves up for an easy transition to Semitic mythology. For instance, Leeming recounts the tale of Gilgamesh $(2,600$ B.C.E.) where the hero, in Tablet 6 , is approached by Ishtar/Inanna who promises him her love and marriage, as well as fertility for himself, his city, and its fields and animals. It is clear here that Ishtar/Inanna is a goddess of sovereignty. Gilgamesh rejects her without the slightest consideration, remarking on the rather tragic ends with which her previous lovers met. Through these means, Ishtar/Inanna is vilified as the goddess responsible for multiple deaths. Leeming finds this refusal of the goddess perplexing and writes:

Gilgamesh's rejection of Ishtar is difficult to understand, given the fact that she was the city goddess of Uruk and that the sacred marriage of king and goddess had been a foundation of Mesopotamian culture at least since the Old Sumerian period. There is the possibility that the incident somehow reflects the demythologizing of divine kings as well as a movement away from the strong goddess aspect of religion and culture to the kind of patriarchy revealed also in the Enuma Elish (59). 
Even more interestingly, we find traces of the mother goddess of the Irish Tuatha de Danaan, [D]Anu, busy in Uruk. After being refused, Ishtar has Anu send the bull of heaven to attack the heroes.

This same "birth of patriarchy" is seen in explicitly Irish tales, namely the Táin Bo Cuailnge. The hero, Cúchulainn is offered sacred marriage by both the Mor-rioghan, whom he rejects, saying "that he had more important things on his mind than sex" (Green $1995,44)$ and once by Queen Medb herself, whom he also rejects (Devlin-Glass 121). Both pursue him with the intent of killing him; in the end, Queen Medb succeeds.

It is certainly possible that these tales of "rejection of the goddess" by the hero represent changing ideologies within the community or influence from outside mythologies. Rejection of the goddess in these myths undoubtedly had its effect on the human psyche, which would have understood the hero as no longer needing women or the divine marriage to validate, protect, and bestow fertility upon the kingdom. This sort of rejection leaves little opportunity for equality between the sexes in the newer JudeoChristian mythology. This inythology would be recorded by those who learned to read and write, namely men, who had already learned from the great heroes, Cúchulainn and Gilgamesh, that women were not a necessary element in creation. Man alone could reflect divinity, and could be created by a divine male god without the aid of a goddess or woman. Ruether writes that for "centuries of orthodox Christianity, the message has been drilled into women that they are second in creation and first in sin, [and] must therefore be doubly submissive, and are good only for childbearing" (Ruether 1985, 86). 
Eller eventually labels all feminist matriarchalists as "myth makers" who are not recounting history, but rather creating one that will explain contemporary crises (Eller $2000,186)$. According to Eller, feminists are interested in reconstructing the past for two reasons; in order to avoid repeating the past errors that created patriarchy and also to help create strategies in the reclamation and liberation of women and earth. Eller perceives the creation of the matriarchal myth, or at least the perpetuation of it, as an "emotionally compelling" one that serves psychological needs. Ultimately, she brings to the forefront the fact that if sexism has a "birth" and if there was a patriarchal revolution that destroyed an ideal matriarchy, it happened in prehistory and is, therefore, something we cannot know. Gross believes the entire debate regarding the birth of patriarchy to be a mute point that has no possibilities for forward evolution towards sustainable egalitarian coexistence between men and women.

While Gross's analysis is probably correct in that little positive progress can be made when the concentration of mental effort is focused on blaming one another, Eller seems in danger, at least with this final comment, of not asking the question at all; if there were goddesses, and there certainly were, from what kind of culture and cosmological paradigm did they originate? Her final comment hides the fact that she must have spent copious hours reading and documenting alternate explanations and theories of evidence that would otherwise corroborate the theory of a matriarchal or goddess-centered prehistory. Eller provides her readers with many points that are hard to argue with; while Gimbutas claims that the bull was a feminine symbol and became so because of the similarity between the shape of its horns and the female reproductive organs, Eller sees 
this as highly improbable. She quotes Tylor in pointing out that the "fallopian tubes are barely visible upon dissection" (Eller 2001, 147).

Of course, this excludes any intuitive understandings that early people may have had regarding their bodies and connecting bulls to the feminine aspect. There seems little question that the myths became more and more male-dominated, reflecting male interests, and eventually rejecting the goddess altogether. While it is important to not buy wholesale into academic trends without asking the difficult questions, and Eller helps save scholars from this mistake, it is also important not to deny pre-historic people any powers of intuition or deduction that were likely well developed (if not "over"developed) before science answered all the questions for them. Gimbutas felt that the "intuitive" people already understood the goddess-centered past and the process of goddess devaluation; academia, in contrast, was just now catching up (www.webcom.com/gimbutas). 


\section{LIST OF REFERENCES}

Brenneman, Walter. "Transformation and Symbolism in the Irish Celtic and IndoEuropean Cattle Raiding Myth: A Symbolic Analysis". Journal of Indo-European Studies 19 (1991): 17-92.

Case, H.J. "Neolithic Explanations". Antiquity 43 (1969):176-86.

Christ, Carol. Rebirth of the Goddess: Finding Meaning in Feminist Spirituality. New York: Addison-Wesley Publishing, 1997.

Clark, Rosalind. The Great Queens: Irish Goddesses from the Morrigan to Cathleen ni Houlihan. London: Colin Smythe Limited, 1990.

Condren, Mary. The Serpent and the Goddess: Women, Religion, and Power in Celtic Ireland. San Francisco: Harper \& Row, 1989.

Cunliffe, Barry, ed. The Oxford Illustrated Prehistory of Europe. New York: Oxford University, 1994.

Daly, Mary. Beyond God the Father: Toward a Philosophy of Women's Liberation. Boston: Beacon Press, 1985.

Dames, Michael. Mythic Ireland. London: Thames and Hudson, 1992.

De Riencourt, Amaury. Sex and Power in History. New York: David McKay Company, 1974.

Devlin-Glass, Frances. "The Sovereignty as Co-Lordship: A Contemporary Feminist Rereading of the Female Sacred in the Ulster Cycle". In Frances Devlin-Glass and Lyn McCredden, eds. Feminist Poetics of the Sacred: Creative Suspicions. Oxford: Oxford University Press, 2001.

Diamond, Jared. Guns, Germs, and Steel: The Fates of Human Societies. New York: W.W. Norton \& Company, 1997.

Eller, Cynthia. The Myth of Matriarchal Prehistory: Why an Invented Past Won't Give Women a Future. Boston: Beacon Press, 2000.

Living in the Lap of the Goddess. New York: Lexington Ave., 1993.

Engels, Frederick. The Origin of the Family, Private Property, and the State. New York: Pathfinder Press, [1884] 1972. 
Epstein, Angelique Gulermovich. "War Goddess: The Morrigan and her Germano-Celtic Counterparts". Ph.D. dissertation, University of California, Los Angeles, 1998. Electronic version \#148, October 2004.

Fisher, Elizabeth. Woman's Creation: Sexual Evolution and the Shaping of Society. New York: Anchor Press, 1979.

Gimbutas, Marija. The Living Goddesses. Berkeley: University of California Press, 1999.

Gray, Elizabeth, ed. Cath Mag Tuired. London: Irish Texts Society, 1998.

, "Cath Maige Tuired: Myth and Structure". Eigse 18 (1981): part 2.

Green, Miranda. Celtic Myths. London: British Museum Press, 1993.

, Celtic Goddesses: Warriors, Virgins, and Mothers. New York: George Braziller Inc., 1996.

Gross, Rita. "The Pre-Patriarchal Hypothesis: An Assessment". Gender/ Bodies/

Religions: Adjunct Proceedings of the XVII Congress for the History of

Religions. Chicago: University of Chicago Press, 1999.

Hennessy, W.M. "The Ancient Irish Goddess of War". Revue Celtique 1 (1870): 32-55.

Joyce, Timothy. Celtic Christianity: A Sacred Tradition-A Vision of Hope. New York: Orbis Books, 1998.

Keller, Catherine. Face of the Deep: A Theology of Becoming. New York: Routledge, 2003.

Kenney, Theresa M. Women Are Not Human: An Anonymous Treatise and Response. New York: Crossroads Publishing, 1998.

Larrington, Carolyne. The Feminist Companion to Mythology. London: Pandora Press, 1992.

Leeming, David. Jealous Gods and Chosen People: The Mythology of the Middle East. Oxford: Oxford University Press, 2004.

Levi-Strauss, Claude. The Elementary Structures of Kinship. Boston: Beacon Press, 1969.

Linzey, Andrew. Christianity and the Rights of Animals. New York: Crossroads Publishing, 1991. 
Low, Mary. Celtic Christianity and Nature: Early Irish and Hebridean Traditions. Edinburgh: Edinburgh University Press, 1996.

Lysaught, Patricia. The Banshee: The Irish Supernatural Death Messenger. Dublin: O’Brien Press, 1986.

McCaffrey, Carmel and Eaton, Leo. In Search of Ancient Ireland: The Origins of the Irish from Neolithic Times to the Coming of the English. Chicago: New Amsterdam Books, 2002.

Mithen, Steven. The Prehistory of the Mind: The Cognitive Origins of Art, Religion, and Science. London: Thames and Hudson, 1996.

O hOgain, Daithi. Myth. Legend \& Romance. New York: Prentice Hall, 1991.

O'Kelly, Michael J. Newgrange: Archaeology, Art, and Legend. London: Thames and Hudson, 1982.

Ruether, Rosemary Radford. Gaia \& God: An Ecofeminist Theology of Earth Healing. San Francisco: Harper and Row, 1989.

, Womanguides: Readings Toward a Feminist Theology. Boston: Beacon Press, 1985.

Sissa, Guilia. "The Sexual Philosophies of Plato and Aristotle". In Georges Duby and Michelle Perrot, eds., A History of Women in the West. Cambridge: Harvard University Press, 1992.

Sjoestedt, Marie-Louise. Gods and Heroes of the Celts. San Francisco: Turtle Island Foundation, 1994.

Stone, Merlin. When God was a Woman. New York: Barnes \& Noble, 1976.

Thomas, N.L. Irish Symbols of 3500. Dublin: Mercier Press, 1988. 